\title{
PRETHODNA EVALUACIJA UKIDANJA UREDA DRŽAVNE UPRAVE U ŽUPANIJAMA
}

Dr. sc. Iva Lopižić *

Doc. dr. sc. Romea Manojlović Toman **
UDK: 352.9:35.078.3(497.5)

35.077.3:352.9(497.5)

DOI: $10.3935 / z p f z .69 .56 .09$

Izvorni znanstveni rad

Primljeno: listopad 2019.

Prema Zakonu o sustavu državne uprave iz 2019. ukidaju se uredi državne uprave kao dosadašnja prvostupanjska tijela državne uprave, a njihovi se poslovi povjeravaju na obavljanje županijama. Cilj rada jest provesti prethodnu (ex ante) evaluaciju ove organizacijske promjene kako bi se procijenilo mogu li se njezini formalni ciljevi zaista ostvariti. Kako bi se evaluacija provela, utvrđuju se predviđanja koja relevantni akteri (predstojnici i voditelji službi ureda državne uprave, pročelnici županijskih upravnih tijela, saborski zastupnici, župani i javnost) imaju od promjene. Na temelju prikupljenih empirijskih podataka identificiraju se koncepcijski i praktični problemi u provođenju ove organizacijske promjene te se utvrđuje da ona ne može ostvariti formalne ciljeve. Rad postavlja i podlogu za naknadnu (ex post) evaluaciju efekata do kojih će ova promjena dovesti.

Ključne riječi: obavljanje poslova državne uprave na teritoriju, uredi državne uprave, preneseni djelokrug, predvidanja aktera o efektima reforme, evaluacija

* Dr. sc. Iva Lopižić, poslijedoktorandica Pravnog fakulteta Sveučilišta u Zagrebu, Trg Republike Hrvatske 14, Zagreb; iva.lopizic@pravo.hr;

ORCID: orcid.org/0000-0002-1157-0602

** Dr. sc. Romea Manojlović Toman, docentica Pravnog fakulteta Sveučilišta u Zagrebu, Trg Republike Hrvatske 14, Zagreb; romea.manojlovic@pravo.hr;

ORCID: orcid.org/0000-0002-0292-0180 


\section{UVOD}

U srpnju 2019. na snagu je stupio novi Zakon o sustavu državne uprave (dalje u tekstu: ZSDU)1, koji uvodi promjene u sustav državne uprave. Prema novom zakonskom uređenju tijela države uprave su ministarstva i državne upravne organizacije, dok središnji državni uredi Vlade i uredi državne uprave u županijama prestaju postojati. ${ }^{2}$ Pritom se središnji državni uredi pretvaraju u oblik državnih upravnih organizacija ${ }^{3}$, a uredi državne uprave u županijama kao dosadašnja prvostupanjska tijela državne uprave trajno se ukidaju. Zakon predviđa da će se poslovi ureda državne uprave posebnim zakonima povjeriti županijama, koje će preuzeti i zaposlenike dotadašnjih ureda državne uprave. Zakon ne propisuje rokove unutar kojih treba doći do prijenosa poslova na tijela županijske uprave ${ }^{4}$, no Vlada je zaključkom od 18. srpnja 2019. ${ }^{5}$ propisala obvezu tijela državne uprave da do 10. rujna 2019. dostave u proceduru sve zakone koje je potrebno promijeniti kako bi se poslovi s ureda državne uprave mogli prenijeti na županije. Izmjene zakona su podnesene i usvojene u hitnom postupku te promjena stupa na snagu 1. siječnja 2020., što je relativno kratak period za pripremu i provedbu cjelokupne organizacijske promjene.

Cilj rada je provesti evaluaciju ukidanja ureda državne uprave u županijama. Pritom se provodi prethodna (ex ante) evaluacija u kojoj se ispituje mogu li se ciljevi organizacijske promjene, formalno navedeni i objašnjeni u službenim dokumentima Sabora i Vlade, ovom promjenom ostvariti. Kako su mjere nužne za implementaciju promjene u međuvremenu započele, evaluacija omogućuje korištenje njezinih rezultata za poboljšanje samog procesa implementacije. Evaluacija postavlja podlogu za naknadnu (ex post) evaluaciju efekata do kojih će ova organizacijska promjena u budućnosti dovesti.

Rad obuhvaća teorijsku raspravu o dekoncentraciji i upravnoj decentralizaciji kao modelima organizacije obavljanja poslova državne uprave na teritoriju i pravno-institucionalnu analizu dosadašnjeg i novog uređenja obavljanja poslova državne uprave na teritoriju Hrvatske. Glavno istraživačko pitanje razmatra se kroz evaluacijski pristup upravnim reformama i promjenama te ono glasi: "Mogu

\footnotetext{
1 Zakon o sustavu državne uprave, Narodne novine, br. 66/2019.

2 Čl. 4. st. 2. ZSDU-a.

3 Čl. 58. st. 2. ZSDU-a.

4 Čl. 67. ZSDU-a.

5 Zaključak Vlade o zaduženjima tijela državne uprave radi usklađivanja sa Zakonom o sustavu državne uprave, KLASA: 022-03/19-07/292 URBROJ: 50301-25/06$19-4$.
} 
li se ovako postavljenom organizacijskom promjenom ostvariti njezini formalni ciljevi?". Kako bi se evaluacija provela, analizom službenih dokumenata Sabora (Strategija razvoja javne uprave za razdoblje od 2015. do 2020. godine), Vlade (Akcijski plan provedbe Strategije razvoja javne uprave za razdoblje od 2017. do 2020. godine, Konačni prijedlog Zakona o sustavu državne uprave) i Ministarstva uprave (Strateški plan Ministarstva uprave za razdoblje 2018. - 2020. godine) utvrđuju se formalni ciljevi promjene. S obzirom na to da je Hrvatska članica Europske unije, a Europska komisija upućuje kontinuirane kritike na izrazitu fragmentaciju hrvatskog sustava javne uprave koja nepovoljno utječe na gospodarski život zemlje, u analizu se uzimaju i stajališta Europske komisije o stanju javne uprave u Hrvatskoj kroz godišnja izvješća u okviru Europskog semestra i Nacionalni program reformi.

Zatim se analizom predviđanja koja relevantni akteri imaju od promjene ispituju njihova predviđanja mogu li se formalni ciljevi ove promjene ostvariti. Relevantni akteri kategorizirani su u tri skupine: a) službenici - predstojnici i voditelji službi ureda državne uprave kao (rukovodeći) državni službenici koji vode/obavljaju poslove u uredima državne uprave čije ukidanje se predviđa te pročelnici županijskih upravnih tijela kao lokalni službenici u čiju nadležnost će poslovi ureda državne uprave biti preneseni, b) politički akteri - saborski zastupnici koji su zakon donijeli te župani kao neposredno izabrani predstavnici županija na koje se poslovi ureda državne uprave prenose te c) šira javnost, s posebnim osvrtom na stručnu javnost. Prilikom analize predviđanja relevantnih aktera primjenjuje se nekoliko istraživačkih metoda: anketa, koja je provedena na uzorku od 302 ispitanika (predstojnici i voditelji službi ureda državne uprave te župani i pročelnici u županijama) s odzivom od njih 149 (49,3\%), analiza saborske rasprave prilikom donošenja ZSDU-a te analiza dokumenata Vlade i javno dostupnih dokumenata u postupku javnog savjetovanja i donošenja ZSDU-a. Pomoćni empirijski materijal su medijski napisi o ovoj organizacijskoj promjeni i donošenju ZSDU-a.

$\mathrm{Na}$ temelju provedenog istraživanja i prikupljenih empirijskih podataka provodi se ex ante evaluacija mogućih učinaka organizacijske promjene. Procjenjuju se šanse da se formalni ciljevi promjene zaista ostvare i raspravlja se o dodatnim, nepredviđenim efektima do kojih ta promjena može dovesti, a na koje su uputili rezultati empirijskog istraživanja. Identificiraju se ključni koncepcijski i praktični problemi u provođenju promjene i formiraju prijedlozi za buduća znanstvena istraživanja. 


\section{OBAVLJANJE POSLOVA DRŽAVNE UPRAVE NA TERITORIJU U REPUBLICI HRVATSKOJ}

\subsection{Dekoncentracija i upravna decentralizacija kao modeli organizacije obavljanja poslova državne uprave na teritoriju}

Iz raznih razloga tehničke i interesne prirode određeni dio poslova državne uprave mora se obavljati na teritoriju. Obavljanje poslova državne uprave na teritoriju može se realizirati kroz dva organizacijska modela: model dekoncentrirane državne uprave, u kojem središnja državna vlast poslove državne uprave dodjeljuje svojim područnim upravnim organima i/ili područnim upravnim jedinicama na teritoriju, te model prenesenog djelokruga, u kojem središnja državna vlast obavljanje poslova državne uprave povjerava jedinicama lokalne samouprave $\mathrm{u}$ njihov preneseni djelokrug. ${ }^{6}$ Prvi organizacijski model institucionalni je rezultat procesa dekoncentracije, dok je drugi organizacijski model institucionalni rezultat procesa upravne decentralizacije. Pojam dekoncentracija potječe iz francuske upravnopravne terminologije, a razvio ga je Léon Aucoc u knjizi Les controverses sur la décentralisation administrative (étude historique) iz 1895., stavljajući ga u opreku pojmu decentralizacija, kojim se označuje prijenos poslova sa središnje državne uprave na tijela jedinica lokalne samouprave. ${ }^{7}$ Pojam upravna decentralizacija potječe iz njemačke upravnopravne terminologije. Kako njemačke lokalne jedinice tradicionalno obavljaju širok krug javnih poslova za državnu vlast, francuska podjela na dekoncentraciju i decentralizaciju kao organizacijske principe obavljanja javnih poslova na teritoriju dograđena je razlikovanjem političke i upravne decentralizacije. Politička decentralizacija označava prijenos poslova državne uprave u samoupravni djelokrug lokalnih jedinica kada lokalne jedinice preko svojih izabranih političkih tijela mogu samostalno odlučivati o obavljanju poslova te podliježu samo ex post nadzoru zakonitosti državne vlasti. Upravna decentralizacija označuje prijenos poslova državne uprave u preneseni djelokrug jedinica lokalne samouprave kada lokalne jedinice ne mogu samostalno odlučivati o prenesenim poslovima i podliježu strogom nadzoru državne vlasti. ${ }^{8}$

6 Lopižić, I., Modeli dekoncentriranog obavljanja poslova državne uprave u postsocijalističkim zemljama, Hrvatska i komparativna javna uprava, vol. 17, br. 1, 2017., str. 81 - 106.

7 Coq, V., Léon Aucoc, constitutionnaliste (1828-1910), 2011., str. 15, http://www.droitconstitutionnel.org/ congres Nancy/comN9/ coqTD9.pdf (14. listopada 2019.).

8 Kuhlmann, S. et al., Dezentralisierung des Staates in Europa. Auswirkungen auf die kommunale Aufgabenerfüllung in Deutschland, Frankreich und Großbritannien, Springer Fachmedien Wiesbaden GmbH, Wiesbaden, 2011., str. 21 - 22; vidi i: Koprić, I. et al., Upravna znanost - javna uprava u suvremenom europskom kontekstu, Pravni fakultet 
Organiziranje obavljanja poslova državne uprave kroz oba organizacijska modela ima određene prednosti i nedostatke. Dekoncentracija poslova državne uprave važna je u fazi formiranja državne vlasti kada je penetracija države u teritorij ključna za kontrolu nedržavnih aktera i procesa na teritoriju, stabilizaciju državne vlasti i legitimiranje državne vlasti pred lokalnim stanovništvom. ${ }^{9}$ Primjena ovog organizacijskog principa važna je u zemljama sa slabo razvijenom lokalnom samoupravom u kojima se dekoncentracija provodi kao korektiv i zamjena za provođenje decentralizacije, odnosno kao dopuna decentralizaciji. ${ }^{10}$ Nadalje, dekoncentracijom se osigurava uniformna primjena propisa na čitavom državnom teritoriju kako bi se svim građanima osigurala dostupnost usluga jednake kvalitete. ${ }^{11}$ Dodjeljivanje poslova dekoncentriranoj državnoj upravi dovodi do modernizacije i povećanja efikasnosti sustava državne uprave organiziranjem državne djelatnosti u teritorijalnim okvirima u kojima je njezino obavljanje najefikasnije uz rasterećenje središnje vlasti od obavljanja poslova i reorijentacije prema poslovima planiranja i nadzora. ${ }^{12}$ Intenzivna dekoncentracija ima negativne posljedice na sustav lokalne samouprave jer može služiti kao instrument centralističkog upravljanja zemljom. Gusta mreža državnih organa i jedinica na teritoriju smanjuje prostor za razvoj autonomne lokalne samouprave, lokalnih inicijativa i vođenje cjelovitih lokalnih javnih politika. ${ }^{13}$

Sveučilišta u Zagrebu i Studijski centar za javnu upravu i javne financije, Zagreb, 2014., str. 280 - 281, $314-315$.

9 Marcou, G., Les enjeux de la présence de l'Etat au niveau territorial, u: Ministere de la fonction publique et de la reforme de l' Etat (ur.), Comptes-rendus de journees d'etude - la comparaison interservices au niveau territorial, Pariz, 2000., str. 7; Van de Walle, S.; Scott, Z., The Role of Public Services in State- and Nation-Building: Exploring Lessons from European History for Fragile States, 2009., str. 9, https:/www.researchgate.net/ publication/228911848_The_Role_of_Public_Services_in_State-and_Nation-Building_Exploring_Lessons_from_European_History_for_Fragile_States (21. listopada 2019.).

10 Marcou, G., Bilan et avenir de la déconcentration, Annuaire des collectivités locales, vol. 22, br. 1, 2002., str. 31.

11 Sauvè, J.-M., Quel modèle d'administration territoriale pour demain?, 2010., str. 2 - 3, http://www.conseil-etat.fr/Actualites/Discours-Interventions/Quel-modele-d-administration-territoriale-pour-demain (21. listopada 2019.).

12 Marcou, op. cit. u bilj. 10, str. 26 i 30.

13 Koprić, I., Proširenje lokalnog samoupravnog djelokruga i sužavanje nadzora središnjih državnih organa, Hrvatska javna uprava, vol. 2, br. 3, 2000., str. 420; Peters, G.; Pierre, J., The SAGE Handbook of Public Administration, SAGE Publications, London, 2003., str. 597. 
S druge strane, upravna decentralizacija može dovesti do jačanja lokalne autonomije, političkog sadržaja lokalne samouprave i kapaciteta lokalnih jedinica. ${ }^{14}$ Njemačka iskustva s upravnom decentralizacijom pokazuju kako povjeravanje poslova lokalnim jedinicama u preneseni djelokrug može dovesti do poboljšanja kvalitete javnih usluga i modernizacije obavljanja javnih službi. ${ }^{15}$ Preduvjet za uspješnu upravnu decentralizaciju su značajan financijski kapacitet, racionalna organizacija te efikasno i profesionalno osoblje lokalne samouprave ${ }^{16}$ jer u protivnom upravna decentralizacija može voditi etatizaciji lokalne samouprave ${ }^{17}$, ograničavanju lokalne autonomije i intervenciji državne vlasti u obavljanje poslova samoupravnog djelokruga ${ }^{18}$ te smanjivanju kvalitete obavljanja poslova iz samoupravnog djelokruga. ${ }^{19}$

Europske zemlje kombiniraju obje varijante rasterećenja središnje državne vlasti od obavljanja poslova državne uprave. Ne postoji nijedna zemlja, bez obzira na veličinu, koja na teritoriju nema dekoncentriranu državnu upravu ${ }^{20}$, a velik dio zemalja eksplicitno predviđa mogućnost da dio poslova državne uprave na teritoriju obavljaju lokalne jedinice u prenesenom djelokrugu. Preneseni djelokrug dominantni je model obavljanja poslova državne uprave jedino u Njemačkoj, čije lokalne jedinice obavljaju oko 80 \% svih javnih poslova na teritoriju, i Češke, koja je ukidanjem okružnih distrikta kao prvostupanjskih tijela državne uprave 2003. njihove poslove povjerila općinama i regijama u preneseni djelokrug. ${ }^{21}$

14 Koprić, I., Lokalna samouprava - nacrt skripta za studij javne uprave, 2005., str. 22 - 23, https://www.pravo.unizg.hr/UZ/dokument (21. listopada 2019.).

15 Banner, G., Local Government - a Strategic Resource in German Public Management Reform, u: Vincent Hoffmann-Martinot, V.; Wollmann, H. (ur.), State and Local Government Reforms in France and Germany, GWV Fachverlage GmbH, Wiesbaden, 2006. str. $139-140$.

16 Koprić, op. cit. u bilj. 14, str. 22 - 23.

17 Wollmann, H. et al., The multi-level institutional setting in Germany, Italy, France and the UK: a comparative perspective, u: Wollmann, H.; Marcou, G. (ur.), The Provision of Public Services in Europe: Between State, Local Government and Market, Edward Elgar, Cheltenham, 2010., str. 22.

18 Koprić, op. cit. u bilj. 14, str. $22-23$.

19 Ministerstvo vnitra ČR, Analýza aktuálniho stavu veřejné správy, 2011., str. 32, http://www.mvcr.cz/soubor/analyza-aktualniho-stavu-verejne-spravy-pdf.aspx (21. listopada 2019.).

20 OECD, Managing across levels of government. Part one: an overview, 1997., str. 27, http:// www.oecd.org/governance/budgeting/1902308.pdf (21. listopada 2019.).

21 Lopižić, I., Utjecaj kapaciteta lokalne samouprave na teritorijalnu državnu upravu, doktorska disertacija, Pravni fakultet, Zagreb, 2017., str. 90 - 94. 


\subsection{Pravno uređenje obavljanja poslova dekoncentrirane državne uprave u Hrvatskoj}

Dosadašnji razvoj obavljanja poslova državne uprave na teritoriju Hrvatske može se pratiti kroz dvije faze: prvu (od 1993. do 2001.), u kojoj su glavni nositelji državne aktivnosti na teritoriju bili županijski uredi, čiji je rad koordinirao župan kao predstavnik državne vlasti na teritoriju i nositelj izvršne vlasti u županijama kao jedinicama lokalne samouprave i uprave ${ }^{22}$, te $\operatorname{drugu}$ (od 2001. do donošenja novog ZSDU-a), koja je počela donošenjem Zakona o lokalnoj i područnoj (regionalnoj) samoupravi ${ }^{23}$ i izmjenama Zakona o sustavu državne uprave $^{24}$, kojim su županijski uredi integrirani u urede državne uprave u županijama, a župani prestali biti predstavnici državne vlasti u županijama te postali isključivo nositelji izvršne vlasti u županijama kao jedinicama područne (regionalne) samouprave. Tijekom čitavog perioda zakoni kojima je reguliran sustav državne uprave predviđali su mogućnost da središnja tijela državne uprave za obavljanje dijela poslova iz svojeg djelokruga na teritoriju organiziraju područne jedinice. ${ }^{25}$ Poseban oblik organizacije obavljanja poslova državne uprave primijenjen je u Gradu Zagrebu u kojem se nisu ustrojavala prvostupanjska tijela državne uprave, već su poslove državne uprave obavljala gradska upravna tijela u prenesenom djelokrugu. ${ }^{26}$

Institucionalni razvoj županijskih ureda odnosno ureda državne uprave kao prvostupanjskih tijela državne uprave karakterizira kontinuirano smanjivanje njihove uloge u upravljanju na teritoriju. Dok je 1997. broj zaposlenih u županijskim uredima dosezao $7066^{27}$, 2019. je u uredima državne uprave zaposleno oko 2500 zaposlenika. $\mathrm{U}$ istom periodu financijska sredstva ureda smanjila su se za više od 40 \% (s 517.192.485,00 kuna u 1998. na 303.489.060,79 kuna u

\footnotetext{
Lopižić, I., Dekoncentrirane državne službe i lokalna samouprava: faktor kapaciteta, u: Musa, A. (ur.), Izazovi upravljanja: decentralizacija i dekoncentracija obavljanja javnih poslova, Friedrich-Ebert-Stiftung i Institut za javnu upravu, Zagreb, 2018., str. 33 - 34.

23 Zakon o lokalnoj i područnoj (regionalnoj) samoupravi, Narodne novine, br. $30 / 2001$.

24 Zakon o izmjenama i dopunama Zakona o sustavu državne uprave, Narodne novine, br. 59/2001.

25 Čl. 4. ZSDU-a, Narodne novine, br. 75/1993; čl. 4. ZSDU-a, Narodne novine, br. $150 / 2011$.

26 Čl. 4. st. 2. Zakona o Gradu Zagrebu, Narodne novine, br. 62/2001, 125/2008, 36/2009, 119/2014, 98/2019.

27 Ivanišević, S. et al., Local Government in Croatia, 2001., str. 231, http://unpanl.un.org/ intradoc/groups/public/documents/untc/unpan017042.pdf (21. listopada 2019.).
} 
2017.). ${ }^{28}$ Smanjivanje personalnog i financijskog kapaciteta ureda dijelom je odraz izdvajanja određenih poslova iz djelokruga ureda i njihova dodjeljivanja drugim akterima na teritoriju. Najveći broj poslova koji je izdvojen iz ureda državne uprave prenesen je na novoustrojene područne jedinice središnjih tijela državne uprave, osobito u području inspekcijskog nadzora. Trend izdvajanja inspekcija iz ureda državne uprave počeo je krajem 90-ih te uredi danas obavljaju inspekcijski nadzor jedino u području rada udruga, skupljanja humanitarne pomoći i sporta. Takav razvoj hrvatske dekoncentrirane državne uprave doveo je do izrazite fragmentacije državnog upravljanja na teritoriju. Prema podacima iz 2016. u upravljanju na teritoriju je uz urede državne uprave i njihove ispostave kojih je 88 sudjelovalo 1279 područnih jedinica sa 28.334 zaposlena. S ureda državne uprave manji dio poslova prenesen je na tijela županija i velikih gradova (graditeljstvo i prostorno planiranje 2007. i poslovi vezani uz okoliš u nešto kasnijem periodu). ${ }^{29} \mathrm{Od} 2015$. do 2018. broj područnih jedinica povećan je s 1279 na 1464 , dakle $14,5 \%{ }^{30}$

Promotre li se navedeni podaci o institucionalnom razvoju dekoncentrirane državne uprave $\mathrm{u}$ kontekstu izrazito fragmentirane strukture hrvatske lokalne samouprave i guste mreže područnih jedinica središnjih državnih agencija, ustanova i asocijacija, zaključuje se kako je upravljanje na teritoriju Hrvatske izrazito razuđeno, s negativnim posljedicama za koordinaciju, efikasnost i druge vrijednosti koje bi se trebale ostvarivati djelovanjem javne uprave. ${ }^{31}$

Analiza sektorskog zakonodavstva, kojim su uredima državne uprave dodijeljeni poslovi, upućuje na to da su uredi državne uprave u županijama uključeni u obavljanje poslova iz područja unutarnjih poslova, poslova u vezi s predstavničkim i izvršnim tijelom, pravosuđa, radnih odnosa, obrazovanja, kulture, zdravstva, socijalne zaštite, prometa, prostornog planiranja i gradnje, primarne proizvodnje te sekundarne i tercijarne gospodarske djelatnosti (Tablica 1). ${ }^{32}$

28 Ministarstvo financija, Izvještaj o izvršenju državnog proračuna, http://www.mfin.hr/ hr/izvrsenje-proracuna (21. listopada 2019.).

29 Lopižić, op. cit. u bilj. 22, str. $37-40$.

30 Ministarstvo uprave, Strateški plan Ministarstva uprave 2019. - 2021., str. 4.

31 Koprić, I., Teritorijalna organizacija Hrvatske: prema novom uređenju, u: Barbić, J. (ur.), Nova upravno-teritorijalna organizacija Hrvatske, Hrvatska akademija znanosti i umjetnosti, Zagreb, 2015., str. 27 - 30.

32 Pri izradi kategorizacije slijedi se klasifikacija razvoja zadaća države i državne uprave prema Pusić, E., Država i državna uprava, Pravni fakultet i Društveno veleučilište, Zagreb, 2007., str. $363-403$. 
Tablica 1. Normativno uređenje poslova ureda državne uprave

\begin{tabular}{|c|c|}
\hline $\begin{array}{l}\text { upravno } \\
\text { područje }\end{array}$ & poslovi u djelokrugu ureda državne uprave \\
\hline $\begin{array}{l}\text { unutarnji } \\
\text { poslovi }\end{array}$ & $\begin{array}{l}\text { - vođenje evidencija o osobnim stanjima građana } \\
\text { - rješavanje o zahtjevu za promjenu osobnog imena } \\
\text { - vođenje registra udruga } \\
\text { - provođenje inspekcijskog nadzora nad radom udruga } \\
\text { - nadzor nad općim aktima predstavničkog tijela jedinica lokalne i } \\
\text { područne (regionalne) samouprave } \\
\text { - odlučivanje o žalbama na odluke izbornog povjerenstva za } \\
\text { - provođenje izbora za mjesne odbore } \\
\text { - rješavanje u postupcima stambenog zbrinjavanja } \\
\text { - davanje prijedloga za razvrstavanje otoka u skupine }\end{array}$ \\
\hline $\begin{array}{l}\text { poslovi u vezi s } \\
\text { predstavničkim } \\
\text { i izvršnim } \\
\text { tijelom }\end{array}$ & - vođenje registra birača \\
\hline pravosuđe & $\begin{array}{l}\text { - pružanje primarne pravne pomoći } \\
\text { - odlučivanje o pravu na sekundarnu pravnu pomoć } \\
\text { - izvještavanje nadležnih tijela o ostvarivanju prava na besplatnu } \\
\text { pravnu pomoć } \\
\text { - provođenje postupka izvlaštenja } \\
\text { - rješavanje o pravu na privilegiranu kupnju dionica } \\
\text { - } \text { sastavljanje smrtovnice }\end{array}$ \\
\hline radni odnosi & $\begin{array}{l}\text { - vođenje evidencija ugovora o radu } \\
\text { - poslovi u vezi s radnim knjižicama }\end{array}$ \\
\hline obrazovanje & $\begin{array}{l}\text { - davanje odobrenja za obavljanje vrtićke djelatnosti i izvođenje } \\
\text { predškolskih programa } \\
\text { - donošenje odluka u vezi s upisom djece u školu } \\
\text { - odlučivanje u vezi s organizacijom nastave } \\
\text { - vođenje evidencije radnika u školskim ustanovama } \\
\text { - utjecanje na rad školskog odbora } \\
\text { - nadzor nad zakonitosti rada i općih akata školskih ustanova } \\
\text { - vođenje registra sportskih djelatnosti } \\
\text { - inspekcijski nadzor u području sportske djelatnosti }\end{array}$ \\
\hline kultura & $\begin{array}{l}\text { - } \text { rješavanje o ispunjavanju uvjeta za osnivanje kazališta } \\
\text { - nadzor nad zakonitosti rada i općih akata pružatelja kazališnih } \\
\text { usluga } \\
\text { - rješavanje o ispunjavanju uvjeta za osnivanje knjižnice } \\
\text { - nadzor nad zakonitosti rada knjižnica } \\
\text { - nadzor nad zakonitosti rada pružatelja muzejskih usluga } \\
\text { - provođenje upravnog nadzora nad radom arhiva } \\
\text { - provođenje nadzora nad zakonitosti rada i općih akata javnih } \\
\text { ustanova u kulturi }\end{array}$ \\
\hline zdravstvo & - rješavanje o pravu na obvezno zdravstveno osiguranje \\
\hline
\end{tabular}




\begin{tabular}{|c|c|}
\hline $\begin{array}{l}\text { upravno } \\
\text { područje }\end{array}$ & poslovi u djelokrugu ureda državne uprave \\
\hline $\begin{array}{l}\text { socijalna } \\
\text { zaštita }\end{array}$ & $\begin{array}{l}\text { - objedinjavanje izvješća o korisnicima prava socijalne skrbi } \\
\text { - sklapanje braka } \\
\text { - sudjelovanje u popisivanju imovine štićenika } \\
\text { - rješavanje o statusnim pitanjima branitelja i stradalih u } \\
\text { Domovinskom ratu } \\
\text { - vođenje evidencije o isplaćenoj pomoći hrvatskim braniteljima } \\
\text { - rješavanje o pravima boraca i civilnih invalida } \\
\text { - rješavanje o statusu prognanika i povratnika } \\
\text { - davanje odobrenja za skupljanje humanitarne pomoći } \\
\text { - vođenje evidencija o prikupljanju humanitarne pomoći } \\
\text { - inspekcijski nadzor nad skupljanjem humanitarne pomoći } \\
\text { - rješavanje o zahtjevima za besplatne udžbenike }\end{array}$ \\
\hline $\begin{array}{l}\text { prostorno } \\
\text { uređenje i } \\
\text { gradnja }\end{array}$ & $\begin{array}{l}\text { - provođenje postupka prijenosa zemljišta na jedinicu lokalne } \\
\text { samouprave }\end{array}$ \\
\hline promet & $\begin{array}{l}\text { - izdavanje posebnih uvjeta za građenje i rekonstrukciju cesta te } \\
\text { davanje suglasnosti na izmjene prometnih projekata } \\
\text { - davanje odobrenja za obavljanje djelatnosti u cestovnom prometu } \\
\text { - provođenje upravnog nadzora u vezi s pomorskim dobrom i } \\
\text { morskim lukama } \\
\text { - izdavanje potvrda o ostvarivanju prava na povlastice u } \\
\text { unutarnjem putničkom prometu }\end{array}$ \\
\hline $\begin{array}{l}\text { primarna } \\
\text { proizvodnja }\end{array}$ & $\begin{array}{l}\text { - obavljanje stručnih poslova u vezi s donošenjem prostornih } \\
\text { planova za poljoprivredno zemljište } \\
\text { - odlučivanje o naknadi za prenamjenu poljoprivrednog zemljišta } \\
\text { - poslovi u vezi s rasplođivanjem stoke i držanjem pčela } \\
\text { - praćenje stanja šumskogospodarskog područja } \\
\text { - izdavanje dopuštenja za korištenje šuma } \\
\text { - vođenje upisnika božićnih drvaca } \\
\text { - vođenje upisnika proizvođača vina }\end{array}$ \\
\hline $\begin{array}{l}\text { sekundarna } \\
\text { gospodarska } \\
\text { djelatnost }\end{array}$ & $\begin{array}{l}\text { - rješavanje o pravu na obavljanje obrtne djelatnosti } \\
\text { - vođenje evidencije o obavljanju obrtne djelatnosti } \\
\text { - rješavanje o pravu na obavljanje rudarske djelatnosti } \\
\text { - vođenje evidencija o rudarskoj djelatnosti }\end{array}$ \\
\hline $\begin{array}{l}\text { tercijarna } \\
\text { gospodarska } \\
\text { djelatnost }\end{array}$ & $\begin{array}{l}\text { - } \text { rješavanje o pravu na obavljanje trgovinske djelatnosti } \\
\text { - rješavanje o pravu na obavljanje ugostiteljske djelatnosti } \\
\text { - vođenje evidencije o pružateljima ugostiteljskih usluga } \\
\text { - rješavanje o pravu na obavljanje turističke djelatnosti } \\
\text { - vođenje evidencija o pružateljima turističkih usluga }\end{array}$ \\
\hline
\end{tabular}

Izvor: Istraživanje sektorskih zakona prikazano u Lopižić, 2017.

Prikaz poslova ureda državne uprave na temelju analize sektorskih zakona daje samo sliku djelokruga ureda državne uprave kakav postoji u formalnim aktima, dok je stvarna opterećenost ureda obavljanjem poslova državne uprave drukčija. Istraživanje Ministarstva uprave o broju predmeta koje su uredi riješili u određenim 
upravnim područjima pokazuje da se uredi u najvećoj mjeri bave obavljanjem poslova prve kategorije (v. Tablicu 1), tj. unutarnjih poslova - poslova opće uprave (čak 83,1 \% slučajeva), a da je njihova uloga u obavljanju drugih poslova vrlo ograničena. ${ }^{33}$

Novi Zakon o sustavu državne uprave previđa znatno odstupanje od dosadašnjeg pravnog uređenja obavljanja poslova državne uprave na teritoriju koje se temeljilo na modelu dekoncentrirane državne uprave, predviđajući ukidanje ureda državne uprave uz povjeravanje njihovih poslova županijama. U prijelaznim i završnim odredbama ZSDU-a predviđa se da će uredi državne uprave $u$ županijama nastaviti s radom do stupanja na snagu posebnih zakona kojima će se pojedini poslovi iz nadležnosti ureda državne uprave povjeriti županijama. ${ }^{34}$ Rokovi za donošenje navedenih zakona nisu propisani, no Vlada je zaključkom od 18. srpnja 2019. ${ }^{35}$ propisala obvezu tijela državne uprave da do 10. rujna 2019. dostave u proceduru sve zakone koje je potrebno promijeniti kako bi se poslovi s ureda državne uprave mogli prenijeti na županije. U zaključku je naglašeno da to ne uključuje poslove upravnog i inspekcijskog nadzora te poslove nadzora nad zakonitosti općih akata, koji će biti preneseni središnjim tijelima državne uprave. Ministarstvo uprave najprije je tvrdilo da je riječ o promjeni 75 zakona, devet uredbi i 46 pravilnika, dok je Vlada na svojoj sjednici 12. rujna 2019. u zakonsku proceduru uputila izmjene 6l zakona. ${ }^{36}$ Zakoni su ušli u saborsku proceduru istoga dana te su doneseni po hitnom postupku već početkom listopada 2019., s datumom stupanja na snagu 1. siječnja $2020 .^{37}$

ZSDU normira i pravni položaj predstojnika, službenika i namještenika ureda, određujući kako nastavljaju obavljati poslove na kojima su zatečeni te imaju pravno na plaću prema dosadašnjim rješenjima o radu do donošenja rješenja o rasporedu na odgovarajuća radna mjesta u upravnim tijelima županija. Pritom oni službenici koji bi do 31. prosinca 2025. ostvarili uvjete za starosnu mirovinu, a koji se do l. listopada 2019. izjasne o sporazumnom prestanku državne službe, ostvaruju pravo na otpremninu. ${ }^{38}$ Prema dostupnim podacima, za ovu se opciju odlučilo 608 službenika ureda državne uprave, što će dovesti do smanjenja od 23 \% (sada je zaposlenih 2544). ${ }^{39}$ Novi ZSDU sadržava posebno poglavlje koje

33 Lopižić, op. cit. u bilj. 22, str. 38.

34 Čl. 67. ZSDU-a.

35 Vlada Republike Hrvatske, op. cit. u bilj. 5.

36 Vlada Republike Hrvatske, 178. sjednica Vlade, 12. rujna 2019., https://vlada.gov.hr/.

37 Hrvatski sabor, Pregled dnevnih redova, https://www.sabor.hr/ (6. prosinca 2019.).

38 Čl. 67. st. 3. i 4. ZSDU-a.

39 Čilić, A., Smanjuje se državni aparat - 608 službenika ide u stimulativnu mirovinu za 97 milijuna kuna, 14. studenog 2019., https://www.rtl.hr/. 
se odnosi na povjeravanje poslova državne uprave jedinicama lokalne i područne (regionalne) samouprave te pravnim osobama s javnim ovlastima. Prema tim odredbama, tijelima jedinica lokalne i područne (regionalne) samouprave mogu se povjeriti samo poslovi neposredne provedbe zakona te drugi upravni i stručni poslovi. ${ }^{40}$ Može se očekivati da će se za obavljanje poslova upravnog i inspekcijskog nadzora koji provode uredi državne uprave ustrojiti nove područne jedinice, što će dovesti do novog povećanja broja područnih jedinica i jačanja fragmentacije. ZSDU određuje da je odgovornost za obavljanje prenesenih poslova na nositeljima izvršne vlasti u jedinicama lokalne i područne (regionalne) samouprave $^{41}$, prateći pritom rješenja ZSDU-a iz 2011.

\section{EVALUACIJSKI PRISTUP, METODOLOGIJA I REZULTATI ISTRAŽIVANJA}

\subsection{Evaluacijski pristup ukidanju ureda državne uprave}

Cilj rada je primjena evaluacijskog pristupa na ukidanje ureda državne uprave u županijama. Bit evaluacije jest dobiti konkretne podatke o svim efektima do kojih pojedina organizacijska promjena može dovesti, dovodi ili je već dovela. Takvi podaci služe za donošenje na dokazima utemeljenih političkih odluka (evidence based policy making), ali i za poduzimanje na dokazima utemeljenih radnji unutar samih upravnih organizacija (evidence based management). Evaluacijske studije primjenjuju se u različitim upravnim područjima, između ostalih i u području upravnih reformi i organizacijskih promjena. ${ }^{42}$

Rad polazi od prethodne (ex ante) evaluacije, evaluacijskog pristupa koji procjenjuje moguće učinke do kojih promjena može dovesti prije nego ona stupi na snagu. Kako su neke radnje nužne za provedbu ukidanja ureda državne uprave $\mathrm{u}$ međuvremenu poduzete, a promjena bi trebala u cijelosti stupiti na snagu 1. siječnja 2020., rad sadržava i elemente tzv. evaluacije za vrijeme provedbe (ongoing), čiji je zadatak prenositi informacije o učincima do kojih neka mjera ili akcija dovode u vrijeme implementacije. Ovakva analiza poslužit će kao temelj

40 Čl. 33. ZSDU-a.

41 Čl. 35. ZSDU-a.

42 Koprić, I.; Wollmann, H., Evaluating Reforms of Local Public and Social Services in Europe, u: Koprić, I.; Wollmann, H.; Marcou, G. (ur.), Evaluating Reforms of Local Public and Social Services in Europe: More Evidence for Better Results, Palgrave Macmillan, 2018., str. $1-18$. 
za naknadnu (ex post) evaluaciju - koja je zapravo klasični oblik evaluacije, a provodi se nakon što je pojedina mjera ili akcija završila. ${ }^{43}$

U ovoj evaluaciji primjenjuje se kombinirani pristup. Prvi, pristup orijentiran ciljevima (u kojem se provodi evaluacija neke politike i mjera s obzirom na ciljeve koji su službeno postavljeni) primijenjen je kod određivanja formalnih ciljeva reformi iz službenih dokumenata. Drugi, pristup utemeljen na teoriji (u kojem se elementi evaluacije određuju na osnovi postojeće teorijske spoznaje) primijenjen je kod ispitivanja predviđanja relevantnih aktera o učincima promjene. ${ }^{44}$

Funkcija ove evaluacije je dvojaka. Ona je deskriptivna jer se prikazuju mogući učinci promjene, ali i eksplanatorna jer sadržava objašnjenje razloga njihove pojave. ${ }^{45}$ Napokon, ova evaluacija uključuje i evaluaciju institucija (daje odgovor na pitanje jesu li se predviđene institucionalne promjene zaista i dogodile), evaluaciju izvedbe (daje odgovor na pitanje hoće li institucionalne promjene dovesti do očekivanih učinaka) te evaluaciju ishoda (koja ispituje hoće li se ostvariti očekivani dugoročni ishodi). ${ }^{46}$ Kada se provodi evaluacija upravnih reformi, kod njih se najčešće mogu evaluirati ulazne vrijednosti (npr. financijske uštede ili smanjivanje broja zaposlenih), promjene u pogledu kvalitete i kvantitete javnih usluga te dugoročne i sistemske promjene u sustavu javne uprave (npr. porast legitimiteta javne uprave od strane građana). ${ }^{47}$ Navedene dimenzije uzimaju se u obzir i u ovoj evaluaciji tako da se prilikom ispitivanja predviđanja relevantnih aktera putem upitnika postavlja niz pitanja od kojih se svako može kategorizirati u jednu od ovih dimenzija (v. Tablicu 3).

Kako bi se ovakva evaluacija mogla provesti, najprije se iz službenih dokumenata definiraju formalni ciljevi koji se promjenom nastoje postići. Zatim se utvrđuju predviđanja koja relevantni akteri imaju od ove promjene, a ona služe

43 Wollmann, H., Utilization of Evaluation Results in Policy-Making and Administration: A Challenge to Political Science Research, Hrvatska i komparativna javna uprava - Croatian and Comparative Public Administration, vol. 16, br. 3, 2016., str. 435 - 436.

Osim toga, postoje još i responzivni i participativni pristup evaluaciji, koje karakterizira veći stupanj fleksibilnosti i participacije aktera, vidi ibid., op. cit. u bilj. 41, str. $8-10$.

45 Ibid., str. 10.

46 Kuhlmann, S.; Wollmann, H., The Evaluation of Institutional Reforms at Sub-national Government Levels: a Still Neglected Research Agenda, Local Government Studies, vol. 37, br. 5, 2011., str. $479-494$.

47 Koprić, I., Evaluacija, novi zakonski okvir i važnost upravljanja učinkovitošću u lokalnoj $i$ regionalnoj samoupravi te u državnoj i javnoj upravi Republike Hrvatske, u: Koprić, I.; Džinić, J.; Manojlović, R., Upravljanje kvalitetom i učinkovitošću u javnoj upravi, Institut za javnu upravu, Zagreb, 2016., str. 11. 
kao jedan od temelja za evaluaciju mogućnosti ostvarenja formalnih ciljeva promjene, ali i uviđanja mogućih pratećih efekata koje će promjena proizvesti.

\subsection{Metodologija istraživanja}

Ciljevi koji se ukidanjem ureda državne uprave žele postići utvrđeni su analizom formalnih dokumenata Sabora (Strategija razvoja javne uprave za razdoblje od 2015. do 2020. godine), Vlade (Akcijski plan provedbe Strategije razvoja javne uprave za razdoblje od 2017. do 2020. godine, Konačni prijedlog Zakona o sustavu državne uprave) i Ministarstva uprave (Strateški plan Ministarstva uprave za razdoblje 2019. - 2021. godine). U obzir se uzimaju i stajališta Europske komisije o stanju javne uprave u Hrvatskoj kroz godišnja izvješća u okviru Europskog semestra te Vladin Nacionalni program reformi za 2019.

Kako bi se ispitala predviđanja relevantnih aktera, u radu je primijenjeno nekoliko metoda istraživanja. Predviđanja predstojnika ureda državne uprave, voditelja službi u uredima državne uprave te župana i pročelnika županijskih upravnih tijela ispitani su online anketom koja je poslana na službeno dostupne e-mail adrese ukupno 302 ispitanika s odazivom 49,3\% (149 ispitanika). Anketa je bila otvorena od 3. lipnja do 3. srpnja 2019., a ispitanicima je dostavljena putem njihove službene $e$-mail adrese. Anketa je sadržavala 26 pitanja u kojima se od ispitanika tražilo da skalom od l (mislim da mjera neće imati učinka) do 4 (mislim da će imati izniman učinak) ocijene u kojoj mjeri očekuju da će najavljena promjena ukidanja ureda državne uprave utjecati na pojedine aspekte upravnog djelovanja. ${ }^{48}$ Ispitanicima je postavljeno i otvoreno pitanje u kojem su mogli iznijeti dodatna predviđanja od promjene. Predviđanja i stavovi političkih aktera ispitani su analizom amandmana podnesenih na ZSDU i komentara saborskih odbora te analizom komentara koji su izraženi u saborskoj raspravi prilikom donošenja ZSDU-a, uz korištenje medijskih napisa kao pomoćnog sredstva analize. Predviđanja i stavovi javnosti analizirani su kroz komentare podnesene u postupku javne rasprave te analizom relevantnih stručnih i znanstvenih radova o promjeni sustava državne uprave u Hrvatskoj (Tablica 2).

48 Ispitanicima je pružena i mogućnost da izaberu odgovor "Ne znam / ne želim odgovoriti”. Postavljena pitanja mogu se vidjeti u Tablici 3. 
Tablica 2. Metodologija istraživanja predviđanja relevantnih aktera

\begin{tabular}{|c|c|}
\hline akteri & primijenjena metoda \\
\hline $\begin{array}{l}\text { službenici } \\
\text { - predstojnici ureda državne uprave u } \\
\text { županijama } \\
\text { - voditelji službe u uredima države } \\
\text { uprave u županijama } \\
\text { - pročelnici županijskih ureda }\end{array}$ & - anketa \\
\hline $\begin{array}{l}\text { politički akteri } \\
\text { - saborski zastupnici } \\
\text { - župani }\end{array}$ & $\begin{array}{l}\text { - analiza mišljenja saborskih odbora i } \\
\text { podnesenih amandmana na Zakon } \\
\text { - analiza komentara saborske rasprave } \\
\text { - anketa } \\
\text { - medijski napisi }\end{array}$ \\
\hline $\begin{array}{l}\text { javnost } \\
\text { - zainteresirana javnost }\end{array}$ & $\begin{array}{l}\text { - analiza savjetovanja sa zainteresiranom } \\
\text { javnošću } \\
\text { - stručni radovi }\end{array}$ \\
\hline
\end{tabular}

Izvor: autorice

\subsection{Formalni ciljevi reforme}

Početkom procesa pridruživanja Europskoj uniji Hrvatska postaje dio europskog upravnog prostora koji sadržava niz načela i standarda postupanja tijela javne uprave. ${ }^{49}$ Nakon ulaska u članstvo, u godišnjim izvještajima u okviru Europskog semestra, Europska komisija izrazila je kritiku zbog izrazito fragmentiranog sustava dekoncentrirane državne uprave jer postojeći sustav dovodi do slabe koordinacije javnih politika, praćenja i evaluacije njihove implementacije $\mathrm{e}^{50}$ te povećavanja troškova i neefikasnosti u trošenju javnih sredstava. ${ }^{51}$ Navedeno predstavlja značajno odstupanje od temeljnih načela europskog upravnog prostora, u prvom redu načela učinkovitosti i djelotvornosti, usklađenosti i transparentnosti. Usprkos kritikama Komisije, svi dosadašnji pokušaji držav-

49 Više o europskom upravnom prostoru vidi u: Koprić, I., European Administrative Space-Myth, Reality, and Hopes, u: Koprić, I.; Kovač, P. (ur.), European Administrative Space: Spreading Standards, Building Capacities, NISPAcee, Bratislava, 2017., str. 31 - 54.

50 Europska komisija, Assessment of the 2014 national reform programme and convergence programme for CROATIA, 2014., str. 36.

51 Europska komisija, Country Report Croatia 2018 Including an In-Depth Review on the prevention and correction of macroeconomic imbalances, 2018., str. 47. 
ne vlasti da se sustav dekoncentrirane državne uprave racionalizira mogu se ocijeniti propalima. ${ }^{52}$

Formalni dokumenti Sabora, Vlade i Ministarstva uprave također upućuju na izrazito fragmentiran sustav upravljanja na teritoriju i neracionalnu organizaciju hrvatske dekoncentrirane državne uprave. Kako bi se racionalizirao postojeći sustav te povećala učinkovitost, transparentnost i dostupnost državnih usluga građanima, Strategija razvoja javne uprave za razdoblje od 2015. do 2020. godine, Akcijski plan provedbe Strategije razvoja javne uprave za razdoblje od 2017. do 2020. godine i Strateški plan Ministarstva uprave za razdoblje 2019. - 2021. godine predvidjeli su jačanje ureda državne uprave. Kao mjere kojima bi se postigao ovaj cilj, dokumenti su predvidjeli pripajanje područnih jedinica uredima državne uprave te prenošenje određenih upravnih poslova i poslova inspekcijskog nadzora sa središnjih tijela državne uprave na urede državne uprave u županijama ${ }^{53}$ Komisija je u svojim izvještajima pozitivno ocijenila mjere predviđene strategijama, pod uvjetom da se one zaista i provedu. ${ }^{54}$

U Vladinu Nacionalnom programu reformi 2019. donesenom u okviru Europskog semestra kao odgovor na zahtjeve Komisije govori se o problemu teritorijalne rascjepkanosti javne uprave te nejasnoj funkcionalnoj raspodjeli nadležnosti, a kao reformske mjere predviđaju se povećanje učinkovitosti obavljanja poslova u jedinicama lokalne samouprave kroz razvoj indikatora za mjerenje kapaciteta lokalnih jedinica, što će poslužiti kao temelj za decentralizaciju poslova državne uprave, odnosno postizanje učinkovitijeg obavljanja poslova državne uprave putem novog normativnog okvira, no bez specificiranja što to znači za urede državne uprave. ${ }^{55} \mathrm{U}$ Konačnom prijedlogu novog ZSDU-a Vlada je odstupila od mjera predviđenih strategijama i umjesto jačanja ureda državne uprave predlaže njihovo ukidanje. Argumenti kojima se opravdava ukidanje ureda državne uprave u Konačnom prijedlogu ZSDU-a sadržajno su jednaki argumentima na temelju kojih su strategije predviđale jačanje ureda državne

52 Koprić, I., Public Administration Reform in Croatia: Slow Modernization During Europeanization of Resilient Bureaucracy, Public Administration Issue, Special Issue I, 2019., str. 22 .

53 Hrvatski sabor, Strategija razvoja javne uprave za razdoblje od 2015. do 2020. godine, str. 45, 54 - 55; Vlada Republike Hrvatske, Akcijski plan provedbe Strategije razvoja javne uprave za razdoblje od 2017. do 2020. godine, str. 8 - 10; Ministarstvo uprave, Strateški plan Ministarstva uprave za razdoblje 2019. - 2021. godine, str. 4 - 5.

54 Europska komisija, op. cit. u bilj. 50, str. 52.

55 Vlada Republike Hrvatske, Nacionalni program reformi 2019., 2019., str. 5 i 86. Preuzeto s https://vlada.gov.hr/UserDocsImages//2016/Sjednice/2018/04\%20travnja/93\%20sjednica\%20VRH//93\%20-\%201.pdf (6. prosinca 2019.). 
uprave. Vlada kao razlog ukidanja ureda državne uprave navodi situaciju da uredi, iako tada važećim ZSDU-om određeni kao prvostupanjska tijela državne uprave, obavljaju tek manji dio upravnih stvari, dok su većina upravnih stvari te gotovo svi inspekcijski poslovi i dalje u prvostupanjskoj nadležnosti središnjih tijela državne uprave. ${ }^{56} \mathrm{U}$ Prijedlogu se ističe kako u mnogim slučajevima i u drugom stupnju rješava isto središnje tijelo državne uprave, što je nepovoljno s aspekta pravne zaštite građana. Kao model organizacije obavljanja poslova državne uprave na teritoriju uzima se Grad Zagreb, čija upravna tijela obavljaju poslove državne uprave u povjerenom djelokrugu te se navodi da se takav model u praksi pokazao kao "održiv i učinkovit". ${ }^{57}$

Vlada u Konačnom prijedlogu ZSDU-a ne ističe jasno koji su ciljevi koji se žele ostvariti ukidanjem ureda državne uprave. Ipak, tumačenjem obrazloženja ZSDU-a, kao formalni ciljevi koje Vlada želi ostvariti ukidanjem ureda državne uprave mogu se navesti racionalizacija sustava državne uprave kroz smanjenje broja tijela državne uprave i broja državnih službenika te decentralizacija kroz prijenos poslova u preneseni djelokrug županija. U posljednjem izvješću o Hrvatskoj Komisija ocjenjuje da je mjera ukidanja ureda državne uprave djelomično usmjerena na rješavanje rascjepkanosti sustava državne uprave, ali da učinak te mjere uvelike ovisi o njezinoj učinkovitoj provedbi. ${ }^{58}$

\subsection{Predviđanja službenika: predstojnici i voditelji službi u uredima državne uprave te pročelnici županijskih upravnih tijela}

Anketa je poslana predstojnicima ureda državne uprave u županiji (20), voditeljima službi (82) te pročelnicima u županijama (180), s ukupnim odzivom od $70 \%$ među predstojnicima (14 odgovora), $64 \%$ među voditeljima službi (53 odgovora) te $45 \%$ (81 odgovor) među županijskim pročelnicima.

56 Vlada Republike Hrvatske, Konačni prijedlog zakona o sustavu državne uprave, 2019., str. 20. https://www.sabor.hr (21. listopada 2019.).

Ibid.

58 Europska komisija, Country Report Croatia 2019 Including an In-Depth Review of the prevention and correction of macroeconomic imbalances, 2019., str. 59. 
Tablica 3. Predviđanja službenika od ukidanja ureda državne uprave

\begin{tabular}{|c|c|c|c|c|c|c|}
\hline \multirow{2}{*}{$\begin{array}{l}\text { Mjera u kojoj smatrate da prenošenje } \\
\text { poslova ureda državne uprave na } \\
\text { županije utječe na: } \\
\text { 1 - Mislim da neće imati nikakav učinak } \\
2 \text { - Mislim da će imati mali učinak } \\
3 \text { - Mislim da će imati srednji učinak } \\
4 \text { - Mislim da će imati izniman učinak }\end{array}$} & \multicolumn{2}{|c|}{$\begin{array}{l}\text { predstojnici } \\
\text { ureda državne } \\
\text { uprave }\end{array}$} & \multicolumn{2}{|c|}{ voditelji službi } & \multicolumn{2}{|c|}{$\begin{array}{l}\text { pročelnici u } \\
\text { županijama }\end{array}$} \\
\hline & prosjek & $\begin{array}{c}\text { najčešća } \\
\text { vrijednost } \\
\text { (mode) }\end{array}$ & prosjek & $\begin{array}{c}\text { najčešća } \\
\text { vrijednost } \\
\text { (mode) }\end{array}$ & prosjek & $\begin{array}{c}\text { najčešća } \\
\text { vrijednost } \\
\text { (mode) }\end{array}$ \\
\hline $\begin{array}{l}\text { Veća zainteresiranost građana za rad } \\
\text { županijskih tijela i župana }\end{array}$ & 1,64 & 1 & 1,77 & 1 & 2,68 & 3 \\
\hline $\begin{array}{l}\text { Veće uključivanje građana u rad } \\
\text { lokalnih tijela (slanje prijedloga, peticija, } \\
\text { organiziranje zborova građana, mjesni } \\
\text { odbori) }\end{array}$ & 1,50 & 1 & 1,75 & I & 2,36 & 2 \\
\hline Jačanje uloge županijske skupštine & 1,57 & 1 & 2,13 & 2 & 2,94 & 4 \\
\hline Jačanje uloge i važnosti župana & 3,14 & 4 & 3,31 & 4 & 3,53 & 4 \\
\hline $\begin{array}{l}\text { Veću izlaznost na izbore za županijsku } \\
\text { skupštinu i župana }\end{array}$ & 1,57 & 1 & 1,79 & 1 & 2,49 & 3 \\
\hline $\begin{array}{l}\text { Povećanje transparentnosti rada } \\
\text { županijskih tijela (objava informacija i } \\
\text { podataka) }\end{array}$ & 1,86 & 1 & 2,04 & 1 & 2,74 & 3 \\
\hline $\begin{array}{l}\text { Kvalitetniji i uniformniji nadzor države } \\
\text { nad obavljanjem poslova u županijama }\end{array}$ & 1,79 & 1 & 2,06 & $\mathrm{l}$ & 2,79 & 3 \\
\hline $\begin{array}{l}\text { Veći intenzitet nadzora središnje države } \\
\text { nad županijama }\end{array}$ & 1,86 & 1 & 2,06 & 1 & 2,68 & 3 \\
\hline $\begin{array}{l}\text { Intenzivniju suradnju županije i lokalnih } \\
\text { jedinica na njezinom području }\end{array}$ & 2,00 & 2 & 2,19 & 1 & 2,95 & 3 \\
\hline $\begin{array}{l}\text { Poboljšanje suradnje sa središnjim } \\
\text { tijelima državne uprave }\end{array}$ & 1,93 & 2 & 2,08 & 1 & 3,25 & 4 \\
\hline $\begin{array}{l}\text { Poboljšanje koordinacije unutar tijela } \\
\text { županije }\end{array}$ & 1,79 & 1 & 2,10 & 1 & 2,99 & 3 \\
\hline Intenzivniju suradnju između županija & 2,00 & 1 & 2,22 & 2 & 2,69 & 3 \\
\hline $\begin{array}{l}\text { Poboljšanje suradnje s područnim } \\
\text { jedinicama središnjih tijela državne } \\
\text { uprave i drugim javnim tijelima koji } \\
\text { djeluju na području županije }\end{array}$ & 1,86 & 1 & 2,06 & I & 2,86 & 3 \\
\hline $\begin{array}{l}\text { Smanjenje troškova pružanja } \\
\text { decentraliziranih usluga }\end{array}$ & 1,57 & 1 & 1,64 & 1 & 2,65 & 3 \\
\hline $\begin{array}{l}\text { Povećanje brzine pružanja } \\
\text { decentraliziranih usluga }\end{array}$ & 1,36 & 1 & 1,69 & 1 & 3,00 & 4 \\
\hline $\begin{array}{l}\text { Povećanje broja usluga koje se pružaju } \\
\text { građanima u decentraliziranim } \\
\text { područjima }\end{array}$ & 1,36 & 1 & 1,96 & 1 & 3,00 & 4 \\
\hline $\begin{array}{l}\text { Rast osposobljenosti službenika za } \\
\text { pružanje decentraliziranih usluga }\end{array}$ & 1,50 & 1 & 1,77 & 1 & 2,73 & 3 \\
\hline
\end{tabular}




\begin{tabular}{|c|c|c|c|c|c|c|}
\hline \multirow{2}{*}{$\begin{array}{l}\text { Mjera u kojoj smatrate da prenošenje } \\
\text { poslova ureda državne uprave na } \\
\text { županije utječe na: } \\
\text { I - Mislim da neće imati nikakav učinak } \\
2 \text { - Mislim da će imati mali učinak } \\
3 \text { - Mislim da će imati srednji učinak } \\
4 \text { - Mislim da će imati izniman učinak }\end{array}$} & \multicolumn{2}{|c|}{$\begin{array}{l}\text { predstojnici } \\
\text { ureda državne } \\
\text { uprave }\end{array}$} & \multicolumn{2}{|c|}{ voditelji službi } & \multicolumn{2}{|c|}{$\begin{array}{l}\text { pročelnici u } \\
\text { županijama }\end{array}$} \\
\hline & prosjek & $\begin{array}{c}\text { najčešća } \\
\text { vrijednost } \\
\text { (mode) }\end{array}$ & prosjek & $\begin{array}{c}\text { najčešća } \\
\text { vrijednost } \\
\text { (mode) }\end{array}$ & prosjek & $\begin{array}{c}\text { najčešća } \\
\text { vrijednost } \\
\text { (mode) }\end{array}$ \\
\hline $\begin{array}{l}\text { Povećanje/početak korištenja novih } \\
\text { metoda rada (npr. upotreba novih } \\
\text { tehnologija, ispitivanje zadovoljstva } \\
\text { korisnika, strateški pristup organizaciji } \\
\text { pružanja usluga) }\end{array}$ & 1,64 & 1 & 1,98 & 1 & 2,72 & 3 \\
\hline $\begin{array}{l}\text { Rast zadovoljstva građana pruženim } \\
\text { uslugama }\end{array}$ & 1,43 & 1 & 1,67 & 1 & 2,75 & 2 \\
\hline $\begin{array}{l}\text { Smanjenje broja pravnih lijekova koje } \\
\text { građani ulažu na odluke županijskih } \\
\text { tijela }\end{array}$ & 1,00 & 1 & 1,48 & 1 & 2,43 & 3 \\
\hline $\begin{array}{l}\text { Povećanje dostupnosti usluga na cijelom } \\
\text { državnom teritoriju }\end{array}$ & 1,29 & 1 & 1,73 & 1 & 2,70 & 3 \\
\hline $\begin{array}{l}\text { Jednaku kvalitetu decentraliziranih } \\
\text { usluga na cijelom državnom teritoriju }\end{array}$ & 1,57 & 1 & 1,63 & 1 & 2,73 & 3 \\
\hline $\begin{array}{l}\text { Prilagođenost usluga pojedinim } \\
\text { skupinama korisnika }\end{array}$ & 1,50 & 1 & 1,84 & 1 & 2,72 & 3 \\
\hline Povećanje investicija u županiji & 1,71 & 1 & 1,70 & 1 & 2,40 & 2 \\
\hline $\begin{array}{l}\text { Zaustavljanje iseljavanja stanovništva iz } \\
\text { županija }\end{array}$ & 1,14 & 1 & 1,31 & 1 & 1,92 & 1 \\
\hline $\begin{array}{l}\text { Povećanje iskorištenosti sredstava iz } \\
\text { fondova EU-a }\end{array}$ & 2,00 & 1 & 1,80 & 1 & 2,40 & 2 \\
\hline Ukupno & 1,68 & 1 & 1,91 & 1 & 2,73 & 3 \\
\hline
\end{tabular}

Izvor: autorice

Rezultati ankete prikazani u Tablici 3 pokazuju da su predviđanja predstojnika ureda državne uprave i voditelja službi većinom negativna. Kod obje skupine ispitanika postoje samo tri pitanja u kojima se pokazalo da predviđaju da će promjena polučiti barem mali učinak. Naime, predstojnici smatraju da će promjena utjecati na jačanje suradnje županije i lokalnih jedinica na njezinu teritoriju te da će dovesti do poboljšanja suradnje županije sa središnjim tijelima državne uprave. Voditelji službi vide pak mogućnost da promjena u maloj mjeri utječe na jačanje uloge županijske skupštine i na intenzivniju suradnju među županijama. Ono u čemu su obje skupine ispitanika u potpunosti suglasne jest da će ukidanje ureda utjecati na jačanje uloge župana te to vide kao glavni razlog provođenja promjene.

S druge strane, predviđanja županijskih pročelnika većinom su pozitivna te smatraju da će promjena poboljšati gotovo sve aspekte obavljanja poslova koji 
se prenose županijama. Jedini aspekt u kojem pročelnici smatraju da neće doći do bilo kakvih efekata jest zaustavljanje iseljavanja stanovništva iz županije. Aspekt u kojem smatraju da će promjena polučiti najveći efekt jest jačanje uloge i važnosti župana, u čemu su podudarni s predviđanjima službenika iz ureda državne uprave. Uz to, pročelnici smatraju da će promjena imati izniman učinak i na dodatna četiri elementa: poboljšanje suradnje sa središnjim tijelima državne uprave, povećanje brzine i povećanje broja usluga koje se pružaju građanima u decentraliziranim poslovima te jačanje uloge županijske skupštine.

Odgovori koje su ispitanici davali na otvoreno pitanje što očekuju od promjene dali su širi uvid u predviđanja ispitanika. Pročelnici u županijama pokazali su manji interes za odgovaranjem na ovo pitanje. Od ukupno 81 ispitanika, samo njih 20 je odgovorilo na otvoreno pitanje. Dva odgovora bila su neutralna. Od preostalih 18 odgovora, njih čak 12 je pozitivno usmjereno. Pozitivni odgovori mogu se grupirati u tri kategorije: a) promjena će doprinijeti većoj efikasnosti i kvaliteti pruženih usluga, b) promjena će smanjiti preklapanje nadležnosti i olakšati snalaženje građana te c) promjena će doprinijeti ukupnom smanjenju broja zaposlenih i racionalizaciji javne uprave. Negativni komentari upućuju: a) kako je promjena nepripremljena, b) kako promjena dovodi do izostanka prave decentralizacije, c) kako će se povećati broj zaposlenih te d) kako ne mogu sve županije pružiti usluge iste razine kvalitete.

Predstojnici ureda državne uprave dali su sedam odgovora. Dva predstojnika navode da nemaju nikakva očekivanja, dva da će doći do smanjenja broja zaposlenih, ali i pada kvalitete pružanja usluga, dva da će doći do težeg nadzora i veće politizacije u županijama, a jedan navodi da će plaće zaposlenika rasti prelaskom u okvir županije.

Ono što je zabrinjavajuće jesu odgovori koje su dali voditelji službi u uredima državne uprave. Od 53 ispitanika, čak 34 je dalo odgovor na otvoreno pitanje, pri čemu ih je devet napisalo da nemaju nikakva dodatna očekivanja. Samo 11 odgovora može se smatrati pozitivnima, a glavni argument koji ispitanici pritom iznose jest da očekuju povećanje plaća, pri čemu se kao tipičan odgovor može iznijeti: “... povećanje plaća državnih službenika... kao i poboljšanje samih uvjeta rada te drugi niz pogodnosti koje uživaju službenici jedinica područne (regionalne) samouprave, a koja su državnim službenicima u većoj mjeri ukinuta". Osobito je zabrinjavajuće što voditelji službi očekuju da će promjena dovesti do rasta politizacije ("uplitanje političkih aktera u rješavanje zahtjeva stranaka"). Ovo očekivanje je direktno ili indirektno spomenuto kod čak 11 ispitanika.

U saborskoj raspravi prilikom donošenja ZSDU-a državni tajnik Ministarstva uprave jasno je naglasio da ova reforma znači prelazak svih službenika ureda državne uprave u kategoriju županijskih službenika, što im ujedno garantira 
i veću plaću: “...ono što mogu sigurno potvrditi da nijedan zaposlenik ureda državne uprave osim predstojnika neće imati manju plaću nego što to danas ima u uredima državne uprave". Ova informacija trebala bi pozitivno utjecati na stav voditelja službi u uredima državne uprave kojima promjena donosi povećanje plaće. Ipak, rezultati prikazani u Tablici 3 i odgovori na otvoreno pitanje jasno pokazuju da voditelji nemaju pozitivnih predviđanja od promjene te ne očekuju da ona u bilo kojoj mjeri može povećati efikasnosti i kvalitetu obavljanja poslova državne uprave, osim što može dovesti do povećanja njihovih plaća. Štoviše, izražavaju veliku bojazan od povećanja politizacije i interferencije politike u svakodnevno obavljanje poslova.

\subsection{Predviđanja saborskih zastupnika i župana}

Iako je ZSDU organski zakon, njegovo donošenje nije potaknulo širu raspravu u Hrvatskom saboru. Mišljenje o Konačnom prijedlogu zakona dostavila su samo tri odbora: Odbor za zakonodavstvo, Odbor za Ustav, Poslovnik i politički sustav te Odbor za lokalnu i područnu (regionalnu) samoupravu. Pritom se jedino Odbor za lokalnu i područnu (regionalnu) samoupravu dotaknuo ukidanja ureda državne uprave u županijama. Odbor je iznio tri problema zakonskog rješenja prema kojemu se poslovi ureda državne uprave prenose županijama: a) financiranje plaća službenika koje će županije preuzeti - Odbor smatra da bi to pitanje trebalo riješiti povećanjem izvornih prihoda županija (tj. provođenjem prave fiskalne decentralizacije - istaknule autorice), a ne dotacijama iz proračuna. Također, ne zna se ukupan broj djelatnika koje će županije preuzeti jer će neki iskoristiti mogućnost odlaska u mirovinu; b) način prenošenja poslova - Odbor smatra da bi poslove trebalo trajno prenijeti u djelokrug županija, a ne ih samo povjeriti u preneseni djelokrug ( $t$ j. provesti pravu političku, a ne upravnu decentralizaciju - istaknule autorice); c) suglasnost relevantnih političkih stranaka o prihvaćenim rješenjima - Odbor navodi da takva suglasnost ne postoji te će se Zakon mijenjati pri svakoj promjeni središnje državne vlasti. No, bez obzira na iznesene primjedbe, Odbor je o ZSDU-u dao pozitivno mišljenje.

Konačni prijedlog novog ZSDU-a ušao je u saborsku proceduru 30. svibnja 2019. Na prijedlog ZSDU-a podneseno je samo osam amandmana, od čega su prihvaćena četiri: dva vladajućeg HDZ-a i dva Odbora za zakonodavstvo. Ni jedan amandman nije se odnosio na ukidanje ureda državne uprave. Zakon je većinom od 76 glasova (minimalnom većinom potrebnom za donošenje organskog zakona) izglasan 28. lipnja 2019., a stupio na snagu 18. srpnja 2019. Potpuni nedostatak interesa zastupnika za zakonska rješenja novog ZSDU-a uočili su i oporbeni saborski zastupnici: “...nema jako puno ni prijavljenih vezano 
uz raspravu, on ne izaziva veliku nekakvu raspravu u ovoj sabornici a trebao bi". (Anka Mrak Taritaš, GLS).

Analiza saborske rasprave o ZSDU-u od 18. lipnja 2019.59 pokazuje kako vladajuće stranke predviđaju da će promjena dovesti do decentralizacije i racionalizacije državne uprave te približavanja usluga građanima ("konkretno smanjivanje broja tijela državne uprave s 52 na 32" i "smanjivanje broja državnih službenika i namještenika" (Darko Nakić, državni tajnik Ministarstva uprave); "spustit će se uredi državne uprave prema županijama jer oni jesu važni i obavljaju preko 200 poslova" (Josip Borić, HDZ); "učinkovitost, jednostavnost i transparentnost $i$ da građanima budemo servis što i trebamo biti” (Sunčana Glavak, HDZ)). Pozitivnim smatraju i vraćanje na sustav integracije državne i lokalne vlasti kroz figuru župana ("vratit će se to kako je nekad bilo i to je na dobrobit ljudi" (Franjo Lucić, HDZ)). Pozivajući se na ministrove javne istupe, oporbeni zastupnici u saborskoj su raspravi istaknuli kako vladajuća stranka očekuje da će se ovom promjenom opravdati postojanje županija (“...ovo je prilika županijama da opravdaju svoje postojanje” (Tomislav Žagar, Start); “...ministar Kǔ̌čević je rekao tad ćemo opravdat županije” (Anka Mrak Taritaš, GLS)).

Oporbeni zastupnici pozitivnim učinkom promjene ocjenjuju situaciju da će građani na istom mjestu moći primiti širi krug javnih usluga ("kad čovjek treba dobiti neke papire, neke dobiva u svom gradu, nešto je dobivao u uredu državne uprave, nešto je dobio u županiji” (Anka Mrak Taritaš, GLS); "da imamo efikasnu upravu i da građanin zna po što i kod koga ide i da mu se to brzo riješi” (Davor Vlaović, HSS)). Međutim, oporbeni zastupnici iznijeli su i kritike na nova zakonska rješenja. Najveći dio kritika počiva na tezi da prijenos poslova županijama nije prava decentralizacija jer se poslovi samo povjeravaju županijama te proces nije popraćen decentralizacijom sredstava ("ponovno je izostala funkcionalna i financijska decentralizacija" (Tulio Demetlika, IDS); "nema decentralizacije bez financijske decentralizacije" (Tomislav Žagar, Start); “županije za to nemaju sredstava” (Davor Vlaović, HSS)). Dio kritika oporbenih zastupnika odnosi se na nepripremljenost ("cijelo vrijeme imamo jedan intuitivan pristup" (Marko Vešligaj, SDP); "to treba zaista jako dobro pripremiti" (Sabina Glasovac, SDP)) i izostanak suštinske reforme upravljanja na teritoriju (“...na jednoj staroj kući pokušavamo ju malo zakrpati, a ona traži ozbiljnu rekonstrukciju ili u krajnjoj liniji da se sruši i radi nova" (Anka Mrak Taritaš, GLS); "nešto se želi napraviti, ali daleko je to od zacrtanih ciljeva" (Tomislav Žagar, Start)).

59 Analiza saborske rasprave rađena je na temelju transkripta rasprave dostavljenog od strane nadležnih službi Sabora nakon upita postavljenog sukladno Zakonu o pravu na pristup informacijama. 
Predmet kritike bile su i mjere za provedbu promjene - nepostojanje roka za donošenje posebnih zakona ("nitko točno ne zna kada" (Robert Podolnjak, MOST); "bilo bi dobro propisati krajnji rok" (Arsen Bauk, SDP)) te umirovljenje službenika ("da li će oni radije izabrati sporazumni raskid i otpremninu ili će htjeti raditi i dalje za možda i znatno veću plaću nego što su je imali do tada" (Robert Podolnjak, MOST); "svi oni koji imaju 3, 4 ili 5 godina do mirovine to neće prihvatiti" (Darko Vlaović, HSS)) i plaće zaposlenika ureda koji će se premjestiti u županije ("trebat će osigurati dodatna sredstva za plaće" (Tulio Demetlika, IDS)). Dio kritika usmjeren je na opasnost od politizacije do koje ukidanje ureda državne uprave može dovesti ("prilika da neke koji vas ne zadovoljavaju maknete, a neke druge stavite na ta mjesta” (Anka Mrak Taritaš, GLS); “desit će nam se što je bilo 90-ih ...pa će odlučivati župan koji će neka rješenja staviti u ladicu” (Mirando Mrsić, SDP)) i pretvaranja župana u županijske šerife ("onda ste još veći šerif nego što ste bili jučer ukoliko možete još 100 ljudi zbrinuti tamo direktno vi, a da ne morate zvati ministra" i "upravu selimo ... da župani imaju još 200 ljudi pod kontrolom kako bi ovi HDZ-ovi šerifi mogli ... imati koji glas više ili koji glas manje na izborima, zapošljavati ljude i imati još veći utjecaj nego što su imali do sada" (Gordan Maras, SDP); "od I. siječnja 2020. on (župan) postaje oberšerif, a njegova županijska uprava postaje pravi politički nabujak” (Sabina Glasovac, SDP)). Dio oporbenih zastupnika ukidanje ureda državne uprave potaknulo je na raspravu o postojećoj teritorijalnoj organizaciji zemlje (“je li ovakav teritorijalni ustroj zacementiran” (Tomislav Žagar, Start); "treba ukinuti županije, krenuti na regije... ovako će Hrvatska ostat tu di je, a stoji na začelju Europe" (Mirando Mrsić, SDP)) i kritici odluke da se svi poslovi prenesu županijama, a ne i drugim jedinicama lokalne samouprave ("ja sam apsolutno sigurna da za neke poslove trebaju biti i nadležni gradovi" (Anka Mrak Taritaš, GLS); "Zašto isključivo županije? Zašto ne veliki gradovi?" (Robert Podolnjak, MOST)).

Među županima kao predstavnicima županija može se uočiti prevladavanje iznimno pozitivnog stava o ukidanju ureda državne uprave. Anketa je poslana i županima, no samo dvoje ih je ponudilo odgovore, što ne čini reprezentativni uzorak. Ipak, ta dva odgovora daju nagovještaj predviđanja župana. Dok se predviđanja predstojnika ureda države uprave u županijama i voditelja službi mogu ocijeniti ukupnim zbrojem od 1,68 odnosno 1,91, predviđanja župana iznose prosječno čak 3,64 (!), što upućuje na velika očekivanja koja župani imaju od promjene.

Štoviše, čini se da župani jednoglasno podržavaju promjenu (“...svi župani različitih političkih opcija, svi su se složili sa ovim prijedlogom” (Dario Nakić, državni tajnik Ministarstva uprave)). Izjave župana u javnim istupima pokazuju kako župani podupiru vladajuće političke stranke u pogledu motiva za pokretanje promjene i njezinih očekivanih efekata (“županije dobar dio ovih poslova mogu obavljati efikasnije i racionalnije ... ovo je prirodan slijed jer se poslovi vraćaju regional- 
noj samoupravi ... sad se dijete vraća materi" (Goran Pauk, župan šibensko-kninski, HDZ);60 "ovo je ozbilina reforma ... jedan sasvim novi zamah da se dalje ide u dobrom smjeru ... županije konačno postaju ozbiljne institucije" (Radimir Čačić, župan varaždinski, Narodna stranka - Reformisti) ${ }^{61}$ ). Potrebno je uzeti u obzir da čak 12 župana dolazi iz redova vladajućeg HDZ-a, zbog čega je logična njihova velika podrška promjeni. No, ni župani iz oporbenih političkih stranaka nisu se decidirano izjasnili protiv promjene.

\subsection{Predviđanja javnosti}

Prijedlog ZSDU-a podnesen je na javno savjetovanje 8. veljače 2019. s rokom od 15 dana iako Zakon o pravu na pristup informacijama ${ }^{62}$ propisuje da savjetovanja sa zainteresiranom javnošću traju u pravilu 30 dana. Ova nepravilnost primijećena je i u komentarima samog savjetovanja (komentar pučke pravobraniteljice), no u prijedlogu ZSDU-a kao obrazloženje nepoštovanja roka za javno savjetovanje navodi se da je zakon potrebno što prije donijeti kako bi se poštovali rokovi iz Prijedloga Nacionalnog programa reformi za 2019. Također, u obrazloženju Prijedloga zakona navodi se da "treće osobe nisu neposredni adresati predmetnog Zakona", a kao razlog skraćivanja roka navodi se i donošenje niza posebnih zakona kojima će prvostupanjski poslovi državne uprave biti preneseni županijama, zbog čega je potrebno ubrzati proceduru donošenja Zakona. ${ }^{63} \mathrm{~S}$ obzirom na to da je riječ o organskom zakonu koji se zbog svoje važnosti za živote svih građana zemlje i donosi posebnom saborskom većinom, skraćivanje rokova ne može se smatrati opravdanim te znatno onemogućuje šire uključivanje građana u odlučivanje o ustroju i funkcioniraju državne uprave.

U konačnici, interes javnosti za izmjene ZSDU-a bio je slab. Na Prijedlog ZSDU-a podnesen je 31 komentar, od čega šest općih i njih 25 na pojedine odredbe Zakona. Od općih, samo dva komentara tiču se ukidanja ureda državne uprave, a svega jedan komentar dala je građanka koja ukidanje ureda državne uprave

60 Ministarstvo uprave, Ministar Malenica zadovoljan pripremama županija i ureda državne uprave na novu reformu, 6. rujna 2019., https://uprava.gov.hr.

${ }_{61}$ V. B., Čačić otkrio koja mu je najznačajnija reforma koju je Vlada napravila, 26. kolovoza 2019., https://www.tportal.hr; Poslovni dnevnik, Pripajanjem Ureda državne uprave županijama one konačno postaju ozbiljne institucije, 17. listopada 2019., http:// www.poslovni.hr.

62 Čl. 11. st. 3. Zakona o pravu na pristup informacijama, Narodne novine, br. 25/2013, 85/2015.

63 Prijedlog Zakona o sustavu državne uprave, e-savjetovanja, https://esavjetovanja. gov.hr (21. listopada 2019.). 
smatra pozitivnim jer "predstavlja decentralizaciju u smislu olakšavanja građanima ostvarivanja njihovih prava i interesa" te Primorsko-goranska županija. Primorsko-goranska županija upozorila je na sljedeće problematične odredbe novog ZSDU-a: a) neusklađenost pojmova koje ZSDU i Zakon o lokalnoj i područnoj (regionalnoj) samoupravi koriste za označavanje poslova koje obavljaju lokalne jedinice za državnu vlast (povjereni i preneseni poslovi - istaknule autorice), b) nejasnoća jesu li poslovi povjereni županijama državni poslovi ili postaju izvorni poslovi županija, c) nedovoljna i nejasna normiranost statusa službenika koje preuzimaju županije, d) nepostojanje rokova za izmjenu posebnih zakona, zbog čega izostaje cjelokupno i jedinstveno preuzimanje poslova i službenika ureda. Najveći broj posebnih komentara dan je upravo na odredbu o ukidanju ureda državne uprave (njih sedam), no nijedan od strane građana. Sve komentare dala su tijela javne vlasti: Ured pučke pravobraniteljice (1) te Krapinsko-zagorska (4) i Koprivničko-križevačka (2) županija. Komentari problematičnim prepoznaju ista pitanja kao i Primorsko-goranska županija. Komentari su primljeni na znanje, no nije jasno u kojoj mjeri i je li uopće njihov sadržaj uzet u obzir. ${ }^{64}$

Novi ZSDU nije imao veći odjek ni u stručnoj javnosti. Od stručne javnosti cjelovit komentar na novi ZSDU dao je jedino prof. dr. sc. Ivan Koprić, predstojnik Katedre za upravnu znanost Pravnog fakulteta Sveučilišta u Zagrebu. Poput predstojnika i voditelja službi ureda, on u ukidanju ureda vidi opasnost od politizacije zbog mogućnosti da župani kao politički izabrani dužnosnici politički utječu na rješavanje upravnih postupaka iz područja malog i srednjeg gospodarstva. Predlaže da se ugrade jamstva da se to onemogući jer bi takva situacija mogla voditi rušenju ugleda javne uprave u očima građana i poduzetnika te izazvati stručne reakcije, moguće i s razine Europske unije. ${ }^{65}$

\section{EVALUACIJA MOGUĆIH UČINAKA REFORME UKIDANJA UREDA DRŽAVNE UPRAVE}

Formalni ciljevi ukidanja ureda državne uprave su racionalizacija sustava državne uprave i decentralizacija. Međutim, već u obrazloženju Konačnog prijedloga ZSDU-a Vlada ostvarivanje ovih ciljeva potkrepljuje proturječnim argumentima. Prvo, Vlada navodi kako uredi obavljaju samo manji dio prvostupanjskih poslova državne uprave, no istodobno prijenos upravo tih poslova županijama predstavljaju kao decentralizacijsku reformu. Ako je riječ o samo

64 Ibid.

65 Koprić, I., Novi zakoni o državnim službenicima i o sustavu državne uprave, Hrvatska i komparativna javna uprava, vol. 19, br. 2 (poseban prilog), 2019., str. 12. 
manjem krugu poslova državne uprave koji se povjeravaju, tj. prelaze u preneseni djelokrug županija, to nije prava decentralizacija. Dalje, ako Vlada kao problem ističe situaciju da se većina upravnih stvari u prvom stupnju rješava pri središnjim tijelima državne uprave, rješenje se ne može tražiti u ukidanju ureda državne uprave, već u decentralizaciji poslova sa središnjih tijela državne uprave. Također, u Prijedlogu ZSDU-a nije jasno iz kojeg razloga se kao kriterij prijenosa poslova uzimaju samo određene vrste lokalnih jedinica, a ne faktor kapaciteta za obavljanje prenesenih poslova, pa se poslovi s ureda prenose na tijela županija, a ne i na tijela drugih lokalnih jedinica (u prvom redu velikih gradova koji su prijašnjim decentralizacijskim reformama preuzeli poslove ureda državne uprave). Treba uzeti u obzir da će ovom promjenom poslovi biti povjereni županijama u njihov preneseni, a ne samoupravni djelokrug.

Dosadašnja hrvatska iskustva s normativnom regulacijom i praksom obavljanja poslova u prenesenom djelokrugu upućuju na izrazito usku razinu autonomije lokalnih jedinica u njihovu obavljanju, što je protivno čl. 4. st. 5. Europske povelje o lokalnoj samoupravi koju je Hrvatska ratificirala 2008. i bilo je predmetom kritike Kongresa lokalnih i regionalnih vlasti. ${ }^{66}$ Konačno, javno nije dostupna evaluacija obavljanja poslova državne uprave u Gradu Zagrebu, zbog čega ne postoji uporište da je ovakav model zaista efikasniji od postojećeg. Uzimajući u obzir dvosmislenosti, nedorečenosti i nelogičnosti Prijedloga ZSDU-a, i na koncepcijskoj razini ovako postavljena promjena ne može dovesti do ostvarenja formalno postavljenih ciljeva. Jačanje ureda državne uprave kroz integraciju područnih jedinica u urede i prijenos poslova na urede kao mjera predviđena strateškim dokumentima imala bi veći potencijal riješiti problem fragmentiranog (državnog) upravljanja na teritoriju i zaista ostvariti cilj racionalizacije sustava državne uprave, što se ističe kao velik problem u izvještajima Komisije, strateškim dokumentima i znanstvenoj literaturi. Vlada je predvidjela da će se broj službenika smanjiti jer će dio njih iskoristiti priliku za odlazak u prijevremenu mirovinu ${ }^{67}$ No, pritom treba uzeti u obzir da će se njima isplatiti stimulativne mirovine, a da će se plaće preostalih službenika povećati, što jasno potvrđuju svi akteri, zbog čega je upitno hoće li se time postići financijska racionalizacija. Službenici ureda postat će dio županijske uprave, čime se otvara mogućnost dodatnog zapošljavanja. Naime, istraživanje o kretanju broja zaposlenih u jedinicama lokalne samouprave od 1995. do 2013. pokazalo je kako su neke lokalne jedinice prijenos poslova sa središnje vlasti iskoristile za dodatna i

66 Kongres lokalnih i regionalnih vlasti, Local and regional democracy in Croatia, CG31(2016)11 final 20 October 2016, 2016., str. 20 - 21.

67 Čilić, op. cit. u bilj. 391. 
netransparentna zapošljavanja ${ }^{68}$, zbog čega postoji bojazan da će se to dogoditi i u ovoj situaciji.

Predviđanja relevantnih aktera potvrđuju nemogućnost ostvarivanja formalnih ciljeva promjene, ali i upućuju na niz dodatnih efekata do kojih će promjena dovesti.

Akteri su suglasni da će ovom promjenom ojačati institucionalni položaj županija. Uzevši u obzir takve stavove i predviđanja svih aktera te činjenicu da promjena nije predviđena ni u jednom strateškom dokumentu, izvjesno je da je jedini razlog provođenja promjene opravdanje postojanja županija. Jačanje položaja županija valja tumačiti iz perspektive da reforma predstavlja upravnu, a ne političku decentralizaciju, što ističe značajan krug aktera. Poslovi ureda državne uprave županijama se daju u preneseni djelokrug, što znači da županije nemaju regulacijsku ovlast u odnosu na prenesene poslove, već djeluju kao produžena ruka državne vlasti primjenjujući centralno definirane propise u pojedinačnim upravnim stvarima. Ovakva situacija dovodi do sljedeće posljedice: poslovi se ne približavaju građanima jer županijske skupštine nad njima nemaju regulacijsku ovlast, a istodobno jača izvršna vlast u županijama koja nadzire, usmjerava i koordinira županijska upravna tijela koja te propise provode. Time se nastavlja trend jačanja izvršne vlasti u jedinicama područne (regionalne) samouprave, čiji su temelji postavljeni donošenjem tzv. lex šerifa. ${ }^{69}$ Ovakvo institucionalno rješenje omogućuje izvršnim čelnicima da utječu na rješavanje u pojedinačnim upravnim stvarima, što je kao problem prepoznato kod ispitanika iz redova voditelja službi ureda, oporbenih zastupnika i stručne javnosti.

Prijenos poslova u preneseni djelokrug županija vodi do integracije državne i lokalne vlasti u instituciji župana, što župani i vladajuća stranka ocjenjuju pozitivnim pomakom. Međutim, tijekom 90-ih, kada je bio primijenjen model integracije državnih i lokalnih službi pod vodstvom župana, župan je na teritoriju ponajprije djelovao kao predstavnik državne vlasti, a tek onda kao predstavnik specifičnih županijskih interesa. ${ }^{70}$ Danas je temeljna uloga župana predstavljanje i zastupanje interesa stanovništva županije. Upitno je znače li pozitivna

68 Vidi u: Marčetić, G.; Lopižić, I., Utjecaj procesa decentralizacije na jačanje personalnog kapaciteta jedinica lokalne i područne (regionalne) samouprave, Hrvatska i komparativna javna uprava, vol. 17, br. 3, 2017., str. 429.

69 Vidi detaljnije u: Koprić, I., Novela Zakona o lokalnoj i područnoj (regionalnoj) samoupravi iz 2017., u: Koprić, I. (ur.) Europeizacija hrvatske lokalne samouprave, Institut za javnu upravu, Zagreb, 2018., str. 57 - 102.

70 Vidi detaljnije u: Koprić, I., Uloga županija u hrvatskom sustavu lokalne samouprave $i$ uprave 1990-ih i perspektive regionalizacije nakon Promjena Ustava iz 2000. godine, Hrvatska javna uprava, vol. 3, br. 1, 2001., str. $21-62$. 
predviđanja župana u pogledu ponovne integracije državne i lokalne vlasti da žele ojačati vezu sa središnjom državom i strankom na vlasti ili da samo žele ojačati svoju političku važnost u sustavu vlasti. Komparativna iskustva europskih zemalja upućuju na opći trend prema dezintegraciji državne i lokalne vlasti. ${ }^{71}$ Model kakav će biti primijenjen u Hrvatskoj postoji samo u nekim njemačkim saveznim zemljama i Češkoj, no s različitim efektima na upravljanje na teritoriju. Uspješnost njemačkog iskustva proizlazi iz okolnosti duge institucionalne tradicije prenesenog djelokruga, značajnog kapaciteta lokalnih jedinica i duboko ukorijenjene vrijednosti političke decentralizacije, dok neuspjeh češkog iskustva proizlazi iz nepripremljenosti reforme, fragmentirane i slabo kapacitirane lokalne samouprave te nerazvijene političke decentralizacije.

Nažalost, trenutačna situacija u Hrvatskoj bliža je češkom slučaju. Reforma ukidanja ureda državne uprave nije pripremljena i ne pristupa upravljanju na teritoriju holistički, uzimajući u obzir sve aktere koji sudjeluju u tom procesu.

Na ovako zamišljen način, jedino što se reformom sigurno postiže jest zaštita županija kao drugostupanjskih samoupravnih jedinica i petrificiranje postojećeg teritorijalnog ustroja zemlje, koji je predmetom kontinuirane kritike znanstvenih krugova ${ }^{72}$ jer on, među ostalim, stvara fragmentiranu i slabo kapacitiranu lokalnu samoupravu, što teško može doprinijeti jačanju kulture političke decen-

${ }_{71}$ Vidi u: Marcou, G., Le représentant territorial de l'État et le fait régional dans les États Européens, Revue française d'administration publique, vol. 14, br. 3, 2010., str. 567 582.

72 U organizaciji HAZU-a održan je 2015. okrugli stol "Nova upravno-teritorijalna organizacija Hrvatske”, na kojem su znanstvenici iz različitih područja kritizirali postojeću teritorijalnu podjelu zemlje predlažući nova rješenja. Tako je prof. dr. sc. Ivan Koprić s Pravnog fakulteta Sveučilišta u Zagrebu u radu Teritorijalna organizacija Hrvatske: prema novom uređenju dao sliku stanja i problema hrvatske lokalne samouprave s nizom prijedloga preuređenja. Izv. prof. dr. sc. Aleksandar Toskić i prof. dr. sc. Dražen Njegač s Geografskog odsjeka Prirodoslovno-matematičkog fakulteta Sveučilišta u Zagrebu u radu Urbani sustav kao osnova nove upravno-teritorijalne podjele Hrvatske dali su prijedlog podjele Hrvatske na pet regija i 123 urbana centra. Ekonomski pristup problemu teritorijalne podjele primijenjen je u radovima prof. dr. sc. Mladena Vedriša Ekonomske odrednice nove teritorijalne podjele Hrvatske s Pravnog fakulteta Sveučilišta u Zagrebu i u radu Josipa Jambrača Ljudi, ekonomija i teritorijalni ustroj, koji su utvrdili slabu učinkovitosti hrvatske lokalne samouprave i neravnotežu u razvijenosti različitih dijelova zemlje. Izv. prof. dr. sc. Vedran Đulabić s Pravnog fakulteta Sveučilišta u Zagrebu u radu Regionalni razvoj $i$ županije u Hrvatskoj upozorio je na fragmentaciju sustava lokalne samouprave koja onemogućuje regionalni razvoj, razvoj slabije razvijenih područja i apsorpciju sredstava europskih fondova. Radovi su objavljeni u zborniku Barbić, J. (ur.), Nova upravno-teritorijalna organizacija Hrvatske, Hrvatska akademija znanosti i umjetnosti, Zagreb, 2015. 
tralizacije. Reforma će uz porast broja zaposlenih u županijskoj upravi dovesti do i bujanja organizacijskog aparata županija, zbog čega će biti još teže provesti reformu teritorijalnog preustroja. Dodatno, zbog izrazitih razlika u kapacitetu i ostalim obilježjima, moguće je da se poslovi ureda državne uprave neće obavljati na unificiran i jednako kvalitetan način u svim županijama. ${ }^{73}$

Analiza predviđanja relevantnih aktera pokazala je uz naprijed navedene koncepcijske probleme i niz praktičnih problema s kojima će se županije susreti prilikom preuzimanja službenika i poslova iz ureda državne uprave. U proceduri saborske i javne rasprave pokazalo se da nepripremljenost reforme i iznimno kratak period od osmišljanja do implementacije dovode do toga da županije gotovo do samog početka implementacije reforme nisu znale koliko će im službenika biti preneseno, kada će poslovi biti preneseni i iz kojih sredstava će se preuzeti službenici financirati. Ovakav pristup izazvat će nepotrebne financijske troškove za županije i/ili veću financijsku ovisnost županija o pomoći državne vlasti. Deklarirani cilj smanjivanja rashoda za zaposlene teško će se moći ostvariti jer će službenici iz državne uprave prijeći u županijsku upravu, gdje su veće plaće, a one se također financiraju javnim sredstvima.

\section{ZAKLJUČAK}

U radu je provedena ex ante evaluacija organizacijske promjene ukidanja ureda državne uprave i povjeravanja poslova koje su uredi obavljali na županije. Formalni ciljevi koji su promjenom trebali biti ostvareni odnose se na racionalizaciju sustava državne uprave i decentralizaciju. Kako bi se ispitalo hoće li se ovi formalni ciljevi ostvariti, provedeno je istraživanje predviđanja relevantnih aktera o efektima koje očekuju od promjene, nadopunjeno pravno-institucionalnom analizom. Istraživanje je pokazalo da većina aktera, uz iznimku saborskih zastupnika vladajuće političke stranke i župana, smatra kako navedena reforma neće dovesti do racionalizacije sustava državne uprave ni do decentralizacije. Relevantni akteri predviđaju da se cilj racionalizacije možda neće postići, a postoji i bojazan da će promjena dovesti do novih, moguće netransparentnih zapošljavanja u županijskoj upravi koja će biti pod kontrolom pojedinog župana. Relevantni akteri predviđaju da se cilj decentralizacije neće ostvariti jer povjeravanje poslova državne uprave županijama predstavlja upravnu, a ne političku decentralizaciju te nije popraćena fiskalnom decentralizacijom. Također, ističu

73 Vidi detaljnije u: Đulabić, V., Harmonizacija regionalne samouprave u Europi i regionalno pitanje u Hrvatskoj, u: Koprić, I. (ur.), Europeizacija hrvatske lokalne samouprave, Institut za javnu upravu, Zagreb, 2018., str. 447 - 470. 
da prava decentralizacija treba uključivati prijenos poslova državne uprave na sve lokalne jedinice koje imaju dostatno kapaciteta da te poslove obavljaju, a ne samo županije.

Istraživanje predviđanja relevantnih aktera, poduprto rezultatima pravno-institucionalne analize razvoja teritorijalnog upravljanja u Hrvatskoj, upozorilo je na prateće efekte koji bi se mogli dogoditi provođenjem promjene. Ono što se pokazalo kao prevladavajuće predviđanje ispitanika jest da je pravi cilj promjene opravdanje postojanja županija i jačanje položaja župana s efektima politizacije na županijskoj razini i petrificiranja postojeće teritorijalne strukture zemlje. Predviđanja su upozorila na moguće poteškoće u provedbi promjene zbog njezine nepripremljenosti. Dodatni predviđeni efekti promjene su nejednakost pružanja usluga građanima i dodatna financijska opterećenja za županije. Jedino općeprihvaćeno pozitivno predviđanje svih aktera oko efekta koji će se promjenom ostvariti jest da će građani na istom mjestu moći primiti širi krug javnih usluga.

Evaluacijom je potvrđen nalaz iz prethodnog znanstvenog istraživanja $\mathrm{a}^{74} \mathrm{da}$ se razvoj hrvatske dekoncentrirane državne uprave, uz sistemski pristup koji se u hrvatskoj upravnoj znanosti tradicionalno koristi za razumijevanje odnosa državne i lokalne vlasti ${ }^{75}$, treba razumijevati i kroz druge teorijske pravce. Mjera kojom bi se ostvario formalni cilj racionalizacije sustava državne uprave i postavili neki od preduvjeta za provođenje decentralizacije jest reforma područnih jedinica. Za objašnjenje zašto se odlučilo ukinuti urede državne uprave, a ne provesti navedenu mjeru bile bi podesne organizacijske teorije koje djelovanje upravnih organizacija i njihovih širih sklopova promatraju iz perspektive odnosa moći (teorija birokratske disfunkcije i teorija organizacijskog konflikta i moći) ili teorije o patološkom rastu upravnih organizacija i teorije o organizacijskoj autarkiji. Nalazi ovog istraživanja upućuju i na znanstvenu plodonosnost teorije decizionističkog pravca, koji proučava procese donošenja odluka u organizacija$\mathrm{ma}^{76}$ kao teorijskog polazišta za razumijevanje razvoja upravljanja na teritoriju Hrvatske, čime se otvara prostor za buduća znanstvena istraživanja.

Konačno, ovom evaluacijom postavljena je podloga za naknadnu (ex post) evaluaciju učinaka do kojih će promjena dovesti. Naime, bit će zanimljivo s određenim vremenskim odmakom nakon provođenja promjene replicirati

74 Lopižić, op. cit. u bilj. 21, str. 389.

75 Vidi, primjerice, Pusić, E., Upravni sistemi, Grafički zavod Hrvatske i Pravni fakultet, Zagreb, 1985.; Ramljak, M., Centralna i lokalna uprava u razvoju, Centar za društvena istraživanja, Zagreb, 1982.; Ivanišević, S., Izvršni sloj u lokalnoj samoupravi, Pravni fakultet, Zagreb, 1987.

76 O pravcima u teoriji organizacije vidi opširnije u: Koprić, I., Struktura i komuniciranje u upravnim organizacijama, Pravni fakultet, Zagreb, 1999. 
istraživanje sa svrhom da se ispitaju učinci koje je promjena zaista polučila. Na ovaj način rad otvara prostor za daljnja istraživanja i buduće donošenje odluka utemeljenih na dokazima o upravljanju na teritoriju Hrvatske.

\section{LITERATURA}

Banner, G., Local Government- a Strategic Resource in German Public Management Reform, u: Hoffmann-Martinot, V.; Wollmann, H. (ur.), State and Local Government Reforms in France and Germany, GWV Fachverlage GmbH, Wiesbaden, 2006.

Barbić, J. (ur.), Nova upravno-teritorijalna organizacija Hrvatske, Hrvatska akademija znanosti i umjetnosti, Zagreb, 2015.

Coq, V., Léon Aucoc, constitutionnaliste (1828-1910), 2011., http://www.droitconstitutionnel.org/congresNancy/comN9/ coqTD9.pdf

Đulabić, V., Harmonizacija regionalne samouprave u Europi i regionalno pitanje u $\mathrm{Hr}$ vatskoj, u: Koprić, I. (ur.), Europeizacija hrvatske lokalne samouprave, Institut za javnu upravu, Zagreb, 2018., str. 447-470,

Ivanišević, S., Izvršni sloj u lokalnoj samoupravi, Pravni fakultet, Zagreb, 1987.

Ivanišević, S. et al., Local Government in Croatia, 2001., http://unpanl.un.org/ intradoc/groups/public/documents/untc/unpan017042.pdf

Koprić, I., Struktura i komuniciranje u upravnim organizacijama, Pravni fakultet, Zagreb, 1999.

Koprić, I., Proširenje lokalnog samoupravnog djelokruga i sužavanje nadzora središnjih državnih organa, Hrvatska javna uprava, vol. 2, br. 3, 2000., str. 39l-437.

Koprić, I., Uloga županija u hrvatskom sustavu lokalne samouprave i uprave 1990-ih i perspektive regionalizacije nakon Promjena Ustava iz 2000. godine, Hrvatska javna uprava, vol. 3, br. 1, 2001., str. 21-62.

Koprić, I., Lokalna samouprava - nacrt skripte za studij javne uprave, 2005., https:// www.pravo.unizg.hr/UZ/dokument

Koprić, I., Teritorijalna organizacija Hrvatske: prema novom uređenju, u: Barbić, J. (ur.), Nova upravno-teritorijalna organizacija Hrvatske, Hrvatska akademija znanosti i umjetnosti, Zagreb, 2015., str. 21-45.

Koprić, I., European Administrative Space- Myth, Reality, and Hopes, u: Koprić, I.; Kovač, P. (ur.), European Administrative Space: Spreading Standards, Building Capacities, NISPAcee, Bratislava, 2017., str. 31-54.

Koprić, I., Novela Zakona o lokalnoj i područnoj (regionalnoj) samoupravi iz 2017., u: Koprić, I. (ur.), Europeizacija hrvatske lokalne samouprave, Institut za javnu upravu, Zagreb, 2018., str. 57-102. 
Koprić, I., Novi zakoni o državnim službenicima i o sustavu državne uprave, Hrvatska i komparativna javna uprava, vol. 19, br. 2 (posebni prilog), 2019., str. 7-14.

Koprić, I., Public Administration Reform in Croatia: Slow Modernization During Europeanization of Resilient Bureaucracy, Public Administration Issue, Special Issue I, 2019., str. 7-26.

Koprić, I. et al., Upravna znanost- javna uprava u suvremenom europskom kontekstu, Pravni fakultet Sveučilišta u Zagrebu i Studijski centar za javnu upravu i javne financije, Zagreb, 2014.

Koprić, I., Evaluacija, novi zakonski okvir i važnost upravljanja učinkovitošću u lokalnoj i regionalnoj samoupravi te u državnoj i javnoj upravi Republike Hrvatske, u: Koprić, I.; Džinić, J.; Manojlović, R., Upravljanje kvalitetom i učinkovitošću u javnoj upravi, Institut za javnu upravu, Zagreb, 2016., str. 3-38

Koprić, I.; Wollmann, H., Evaluating Reforms of Local Public and Social Services in Europe, u: Koprić, I.; Wollmann, H.; Marcou, G. (ur.), Evaluating Reforms of Local Public and Social Services in Europe: More Evidence for Better Results, Palgrave Macmillan, 2018., str. 1-18.

Kuhlmann, S.; Wollmann, H., The Evaluation of Institutional Reforms at Sub-national Government Levels: a Still Neglected Research Agenda, Local Government Studies, vol. 37, br 5, 2011., str. 479-494

Kuhlmann, S. et al., Dezentralisierung des Staates in Europa. Auswirkungen auf die kommunale Aufgabenerfüllung in Deutschland, Frankreich und Großbritannien, Springer Fachmedien Wiesbaden GmbH, Wiesbaden, 2011.

Lopižić, I., Modeli dekoncentriranog obavljanja poslova državne uprave u postsocijalističkim zemljama, Hrvatska i komparativna javna uprava, vol. 17, br. 1, 2017. str. 81-106.

Lopižić, I., Utjecaj kapaciteta lokalne samouprave na teritorijalnu državnu upravu, doktorska disertacija, Pravni fakultet, Zagreb, 2017.

Lopižić, I., Dekoncentrirane državne službe i lokalna samouprava: faktor kapaciteta, u: Musa, A. (ur.), Izazovi upravljanja: decentralizacija i dekoncentracija obavljanja javnih poslova, Friedrich-Ebert-Stiftung i Institut za javnu upravu, Zagreb, 2018., str. 25-44.

Marcou, G., Les enjeux de la présence de l'Etat au niveau territorial, u: Ministere de la fonction publique et de la reforme de l' Etat (ur.), Comptes-rendus de journees d'etude- la comparaison interservices au niveau territorial, Pariz, 2000., str. 7-11.

Marcou, G., Bilan et avenir de la déconcentration, Annuaire des collectivités locales, vol. 22, br. 1, 2002., str. 25-49.

Marcou, G., Le représentant territorial de l'État et le fait régional dans les États Européens, Revue française d'administration publique, vol. 14, br. 3, 2010., str. 567-582. 
Marčetić, G.; Lopižić, I., Utjecaj procesa decentralizacije na jačanje personalnog kapaciteta jedinica lokalne i područne (regionalne) samouprave, Hrvatska i komparativna javna uprava, vol. 17, br. 3., 2017., str. 407-436.

Ministarstvo financija, Izvještaj o izvršenju državnog proračuna, http://www.mfin. $\mathrm{hr} / \mathrm{hr} /$ izvrsenje-proracuna

Ministerstvo vnitra ČR, Analýza aktuálniho stavu veýejné správy, 2011., http:// www.mvcr.cz/soubor/analyza-aktualniho-stavu-verejne-spravy-pdf.aspx

OECD, Managing across levels of government. Part one: an overview, 1997., http://www. oecd.org/governance/budgeting/1902308.pdf

Peters, G.; Pierre, J., The SAGE Handbook of Public Administration, SAGE Publications, London, 2003.

Sauvè, J.-M., Quel modèle d'administration territoriale pour demain?, 2010., http:// www.conseil-etat.fr/Actualites/Discours-Interventions/Quel-modele-d-administration-territoriale-pour-demain

Pusić, E., Upravni sistemi, Grafički zavod Hrvatske i Pravni fakultet, Zagreb, 1985.

Pusić, E., Država i državna uprava, Pravni fakultet i Društveno veleučilište, Zagreb, 2007.

Ramljak, M., Centralna i lokalna uprava u razvoju, Centar za društvena istraživanja, Zagreb, 1982.

Van de Walle, S.; Scott, Z., The Role of Public Services in State- and Nation-Building: Exploring Lessons from European History for Fragile States, 2009., https:// www.researchgate.net/publication/228911848_The_Role_of_Public_Services_in_State_and_Nation-Building_Exploring_Lessons_from_European_History_for_Fragile_States

Wollmann, H. et al., The multi-level institutional setting in Germany, Italy, France and the UK: a comparative perspective, u: Wollmann, H.; Marcou, G. (ur.), The Provision of Public Services in Europe: Between State, Local Government and Market, Edward Elgar, Cheltenham, 2010., str. 15-48.

Wollmann, H., Utilization of Evaluation Results in Policy-Making and Administration: A Challenge to Political Science Research, Hrvatska i komparativna javna uprava - Croatian and Comparative Public Administration, vol. 16, br. 3, 2016., str. 433-458.

\section{Pravni izvori}

Zakon o sustavu državne uprave, Narodne novine, br. 75/1993, 92/1996, 48/1999, 15/2000, 127/2000, 59/2001, 199/2003 i 79/2007 
Zakon o izmjenama i dopunama Zakona o sustavu državne uprave, Narodne novine, br. 59/2001

Zakon o sustavu državne uprave, Narodne novine, br. 150/2011, 12/2013, 93/2016, 104/2016

Zakon o sustavu državne uprave, Narodne novine, br. 66/2019

Zakon o lokalnoj i područnoj (regionalnoj) samoupravi, Narodne novine, br. $30 / 2001$

Zakon o Gradu Zagrebu, Narodne novine, br. 62/2001, 125/2008, 36/2009, 119/2014, 98/2019

Zakona o pravu na pristup informacijama, Narodne novine, br. 25/2013, 85/2015

\section{Dokumenti i strategije}

Akcijski plan provedbe Strategije razvoja javne uprave za razdoblje od 2019. do 2021. godine, https:/uprava.gov.hr/UserDocsImages//Pristup\%20informacijama//Strateški\%20plan\%20Ministarstva\%20uprave\%202019.-2021.\%20 fin2.pdf

Europska komisija, Assessment of the 2014 national reform programme and convergence programme for CROATIA, 2014., https://ec.europa.eu/info/sites/info/files/ file_import/swd2014_croatia_en_0.pdf

Europska komisija, Country Report Croatia 2018 Including an In-Depth Review on the prevention and correction of macroeconomic imbalances, 2018., https:/ec.europa. eu/info/sites/info/files/2018-european-semester-country-report-croatia-en.pdf

Europska komisija, Country Report Croatia 2019 Including an In-Depth Review of the prevention and correction of macroeconomic imbalances, 2019., https://ec.europa.eu/ info/sites/info/files/file_import/2019-european-semester-country-report-croatia_en.pdf

Kongres lokalnih i regionalnih vlasti, Local and regional democracy in Croatia, CG31(2016)llfinal 20 October 2016, 2016.

Strategija razvoja javne uprave za razdoblje od 2015. do 2020. godine, https:// uprava.gov.hr/UserDocsImages//Istaknute\%20teme//Strategija\%20razvoja\%20javne\%20uprave\%20za\%20razdoblje\%20od\%202015\%20\%20do\%20 2020\%20\%20godine.pdf

Strateški plan Ministarstva uprave za razdobolje 2018. - 2020. godine, https://uprava.gov.hr/UserDocsImages//Pristup\%20informacijama//Strate\%C5\%Alki\%20plan\%20Ministarstva\%20uprave\%202018-2020\%20 (2.8.2017).pdf 
Vlada Republike Hrvatske, Konačni prijedlog zakona o sustavu državne uprave, 2019, https:/www.sabor.hr/sites/default/files/uploads/sabor/2019-05-30/161604/ PZ_617.pdf

Vlada Republike Hrvatske, Nacionalni program reformi 2019., 2019., https:// vlada.gov.hr/UserDocsImages//2016/Sjednice/2019/Travanj/153\%20sjednica\%20VRH//Nacionalni\%20program\%20reformi\%202019.pdf

Zaključak Vlade Republike Hrvatske o zaduženjima tijela državne uprave radi usklađivanja sa Zakonom o sustavu državne uprave, KLASA: 022-03/1907/292 URBROJ: 50301-25/06-19-4

\section{Web izvori}

https://esavjetovanja.gov.hr/ECon/MainScreen?entityId=10385

https://uprava.gov.hr/vijesti/ministar-malenica-zadovoljan-pripremama-zupanija-i-ureda-drzavne-uprave-za-novu-reformu/14970

http://www.hrvzz.hr/novosti/hrvatska_zajednica_zupanija

https://www.sabor.hr/hr/konacni-prijedlog-zakona-o-sustavu-drzavne-uprave-drugo-citanje-pz-br-617-predlagateljica-vlada

https://www.tportal.hr/vijesti/clanak/cacic-otkrio-koja-mu-je-najznacajnija-reforma-koju-je-vlada-napravila-20190826

http://www.poslovni.hr/poduzetnik/pripajanjem-ureda-drzavne-uprave-zupanijama-one-konacno-postaju-ozbiljne-institucije-346083

https://www.rtl.hr/vijesti-hr/novosti/hrvatska/3598597/smanjuje-se-drzavni-aparat-608-sluzbenika-ide-u-stimulativnu-mirovinu-za-97-milijuna-kuna/ 


\section{Summary}

\section{Iva Lopižić * \\ Romea Manojlović Toman ${ }^{* *}$}

\section{EX ANTE EVALUATION OF THE COUNTY ADMINISTRATIVE OFFICES ABOLITION}

According to the new State Administration System Act, county administrative offices as first-instance state administration bodies will be abolished and their affairs will be delegated to counties as units of regional self-government. The goal of this paper is to conduct an ex-ante evaluation of this reform so as to determine whether its formal goals can be achieved. In order to conduct the evaluation, the expectations that relevant actors have of this reform are empirically examined. The relevant actors are divided into three groups. The first group comprises county administrative office heads, county administrative offices department chiefs, and heads of county self-government bodies. Their expectations were examined by an online survey. The second group includes political actors (members of the Parliament and county governors) whose expectations are presented through an analysis of the parliamentary debate in the course of passing the State Administration System Act, the analysis of proposals and comments on the Act and their media appearances. The third group includes the public whose expectations are presented through an analysis of the consultation process with the interested public and the publications by leading experts in public administration. Based on the empirical data collected, the conceptual and practical problems in the reform implementation are identified, with the authors concluding that this reform cannot achieve its formal goal. This data can serve as a basis for conducting ex post evaluations of the reform.

Keywords: execution of central state affairs on the territory, county administrative offices, delegated scope of affairs, evaluation

* Iva Lopižić, Ph. D., Postdoctoral Researcher, Faculty of Law, University of Zagreb, Trg Republike Hrvatske 14, Zagreb; iva.lopizic@pravo.hr;

ORCID: orcid.org/0000-0002-1157-0602

** Romea Manojlović Toman, Ph. D., Assistant Professor, Faculty of Law, University of Zagreb, Trg Republike Hrvatske 14, Zagreb; e-mail: romea.manojlovic@pravo.hr;

ORCID: orcid.org/0000-0002-0292-0180 